\title{
Eemian marine mollusks and barnacles from Ristinge Klint, Denmark: hydrodynamics and oxygen deficiency
}

\author{
Jan K. Nielsen ${ }^{1}$, S. Helama ${ }^{2}$, D. Rodland ${ }^{3}$ \& Jesper K. Nielsen ${ }^{4}$
}

1 Statoil ASA, Exploration and Production Norway, P.0. Box 273, N0-7501 Stjørdal, Norway. Corresponding author. Email: bioerosion@yahoo.dk

2 Department of Geology, P.0. Box 64, 00014 University of Helsinki, Finland.

3 George Washington University, Department of Biological Sciences / Geological Sciences Program, 2029 G St. NW, Washington DC 20052, USA.

4 Department of Geology, University of Tromsø, Dramsvn. 201, N-9037 Tromsø, Norway. Present address: SINTEF Petroleum Research, S.P. Andersens vei 15B, N0-7031 Trondheim, Norway.

Manuscript received: August 2006; accepted: June 2007

\begin{abstract}
Taphonomic analysis of Eemian marine mollusks and barnacles at Ristinge Klint on the island of Langeland (Denmark) provides a distinct record of a temporal succession in preservation states. Four different states of preservation are recognized and related to a decreasing hydrodynamic regime in the depositional setting of the Eemian Baltic Sea. The states show a deepening-upward transition from shallow bay environment towards deeper offshore environment. The depositional setting changed significantly in hydrodynamics about 620 and 1550 years into the Eemian (130,000 to 115,000 years BP), according to biostratigraphic correlation with the varves of the Bispingen succession. The taxonomic composition of the paleofauna supports such a deepening-upward interpretation with a contemporaneous change from brackish water to nearly full marine conditions. The sea bottom was affected by at least one period of oxygen deficiency. The analysis also shows that the preservation of shells varies according to differences in shell structures and life habits. Here we show how these differences should be considered in paleoenvironmental reconstructions based on taphonomic analyses. Taphonomy may play an important role in understanding the hydrodynamic conditions within the Eemian Baltic Sea.
\end{abstract}

Keywords: Taphonomy, Mollusca, Cirripedia, Baltic Sea, Eemian, Interglacial, Denmark

\section{Introduction}

During the Eemian (130,000 to 115,000 years BP), relatively deep-water environments limited the northern and northeastern parts of Denmark, while shallow-marine environments prevailed in southern and western Denmark (Konradi, 1976; Knudsen, 1994, 2004; Seidenkrantz \& Knudsen, 1997; Seidenkrantz et al., 2000; Funder et al., 2002). One of the Eemian key localities of southern Denmark, containing deposits of these shallowmarine environments, is the cliff Ristinge Klint on the island of Langeland (Madsen et al., 1908; Fig. 1). J.G. Forchhammer (1842) first studied the Ristinge Klint in 1841. Later, Johnstrup (1882) examined its stratigraphy and tectonic history. Madsen et al. (1908) made a review of previous studies and conducted a thorough study of Ristinge Klint and adjacent localities. V.
Nordmann (1908, 1913, 1928, 1931), examined the taxonomy and paleoecology of mollusks from these localities.

Apart from scarce notes by Nordmann (1908), no attention has been paid to shell preservation. Analyses of taphonomic features are, however, likely to give additional information on paleoenvironmental processes, e.g., hydrodynamic conditions and biological activity. Scanning electron microscopy of taphonomic features and shell structures may further such analyses (e.g., Nielsen, 2004). Careful analysis of these taphonomic characteristics may provide insight regarding whether macrofaunas were preserved within-habitat or transported from nearby areas (e.g., Kidwell \& Bosence, 1991; Nielsen \& Funder, 2003).

This paper provides a taphonomic analysis of Eemian mollusks and barnacles from the Ristinge Klint. To enhance 

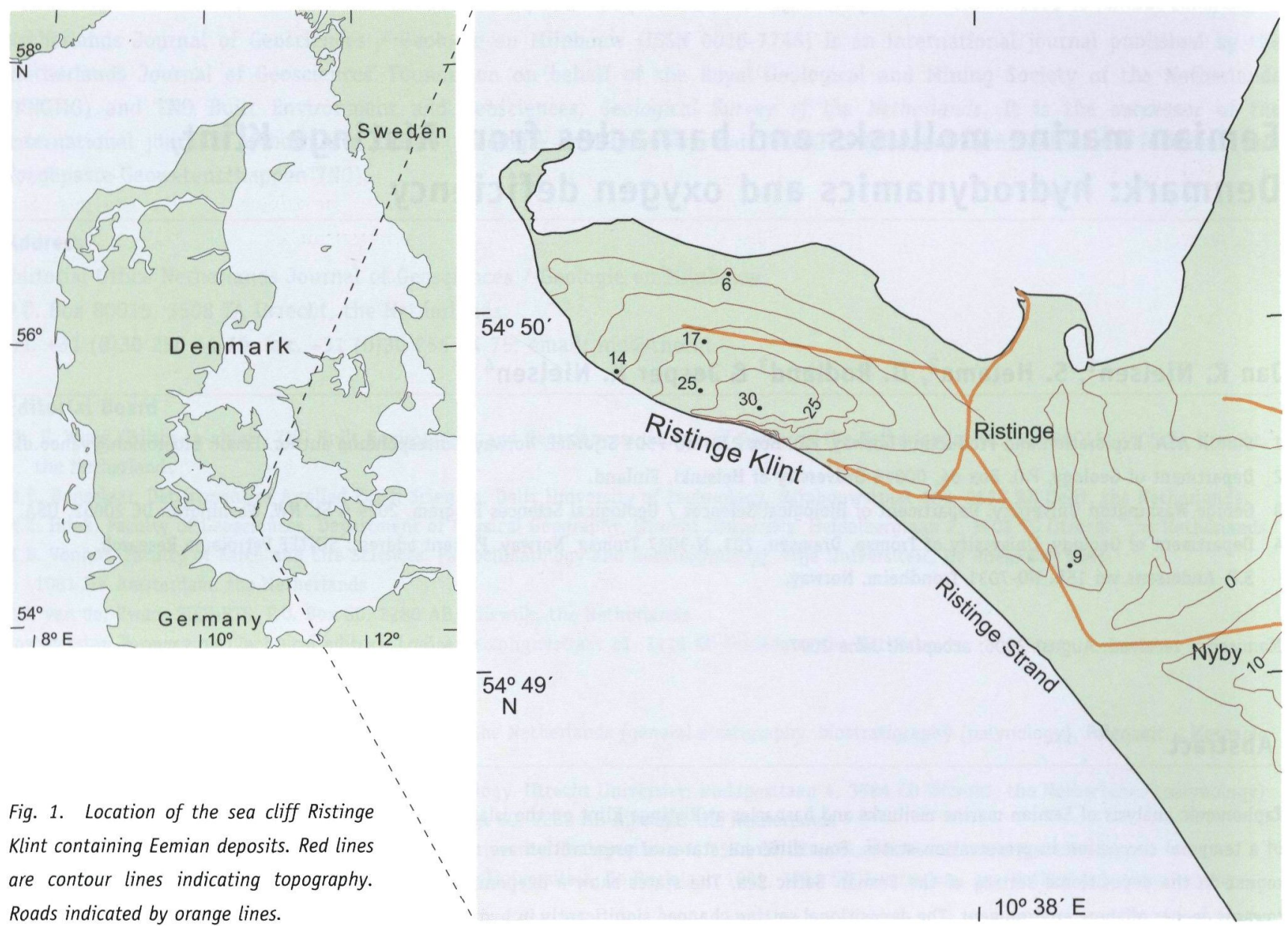

Fig. 1. Location of the sea cliff Ristinge Klint containing Eemian deposits. Red lines are contour lines indicating topography. Roads indicated by orange lines.

the understanding of taphonomic processes and associated features, the analysis includes a shell structural investigation of the most common mollusks. The analysis is the first of such kind on Eemian macrobenthic faunas of Denmark and other areas around the present Baltic Sea. Different states of preservation are defined and placed in the biostratigraphic frame of Kristensen et al. (2000) based on assemblages of foraminifers, ostracods and pollen. This combination of stratigraphic and taphonomic analysis contributes to the understanding of changing hydrodynamic conditions within the Eemian Baltic Sea.

\section{Geological Setting}

The Ristinge Klint is an up to $30 \mathrm{~m}$ high and about $2 \mathrm{~km}$ long cliff situated on the island of Langeland in the southwestern part of the Baltic Sea (Fig. 1). The cliff mainly consists of glaciotectonically thrust-faulted and folded Eemian and Weichselian sediments. The deformation was caused by a prograding Weichselian glacier advancing from a southeasterly direction (Johnstrup, 1882; Madsen et al., 1908; Madsen, 1916; Rosenkrantz, 1945; Sjørring et al., 1982; Sjørring, 1983; Kjær et al., 2003). At least 38 imbricated thrust slices, which show repetition of stratigraphic units, have been recognized.
The thrust slices are numbered in succession (1-38) from northwest toward southeast (Madsen et al., 1908; Kristensen et al., 2000). The Weichselian stratigraphy at Ristinge Klint includes four tills intercalated by various beds of sorted sediments (e.g., Friis \& Larsen, 1974; Sjørring et al., 1982; Sjørring, 1983; Houmark-Nielsen, 1987).

The Eemian stratigraphy at Ristinge Klint includes the sedimentary units 'Shiny clay' and 'Cyprina clay' intercalated by a thin layer of 'Freshwater sand' (Kristensen et al., 2000; see also Madsen et al., 1908; Madsen, 1916; Figs 2, 3). Kristensen et al. (2000) measured stratigraphic levels from the top of the 'Cyprina clay'. This is also done in the present study to calibrate results with their biostratigraphy. The shell-free 'Shiny clay' is interpreted as a lacustrine deposit of early Eemian age, based on pollen (Kristensen et al., 2000). The décollement surface of the tectonic dislocation is situated within the 'Shiny clay'. The 'Freshwater sand' that contains freshwater mollusks was deposited in the margins of a lake (Johnstrup, 1882; Madsen et al., 1908). Reworked clasts of Baltic Saalian till may occur within the sand (Sjørring et al., 1982). The 'Cyprina clay' is up to $232 \mathrm{~cm}$ in thickness of which the lowermost ca. $9 \mathrm{~cm}$ is brackish-water mire. The interval of mire is superposed by ca. $103 \mathrm{~cm}$ of mud. The lower part (ca. $36 \mathrm{~cm}$ thick), where only a single $\mathrm{cm}$-sized shell lens has been 
found, is laminated. The upper part (ca. $67 \mathrm{~cm}$ thick) is structureless with the exceptions of some laminae and four shell-rich horizons. The upper ca. $120 \mathrm{~cm}$ of the 'Cyprina clay' is structureless (Fig. 2).

The biostratigraphic study by Kristensen et al. (2000) was conducted on the Eemian of thrust slices no. 12 and 23. The present study is also based on thrust slice no. 12, allowing us to calibrate the results with their biostratigraphy. This thrust slice contains the thickest succession of the Eemian units. The Eemian is subdivided into five foraminiferal/ostracodal assemblage biozones and four local pollen assemblage biozones. The 'Shiny clay' and the 'Freshwater sand' can be assigned to the Betula-Pinus-Alnus pollen assemblage biozone. The 'Cyprina clay' at Ristinge Klint represents the three pollen assemblage biozones Quercus-Ulmus, Corylus-Quercus and Pinus-Picea-Corylus, representing ca. 3400 years of deposition

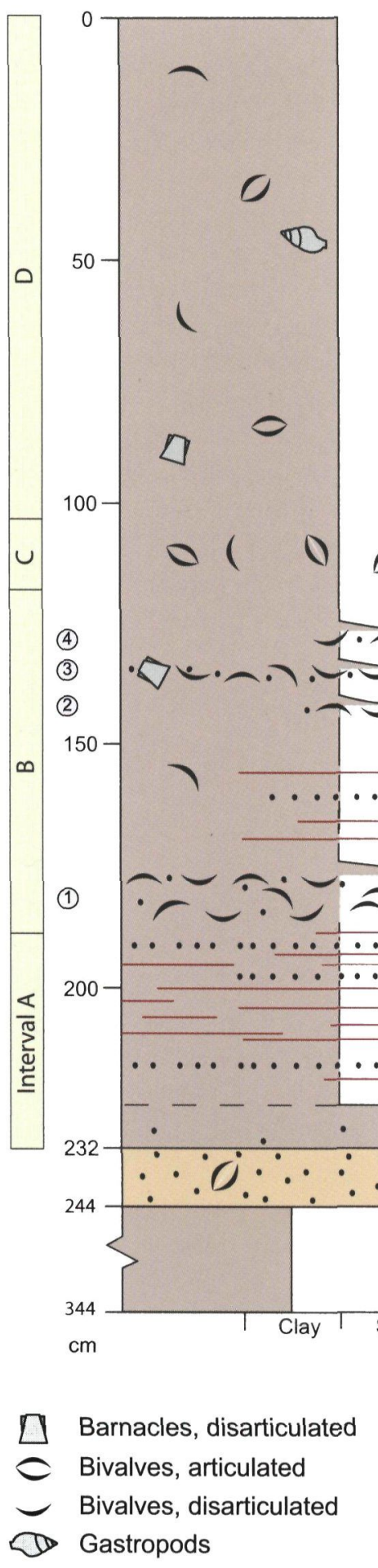

Samples (114-)

Bulk Hand-picked

570

556

555

568

567

566

565

564

569 
(Kristensen et al., 2000). The marine transgression characterized by low salinity took place during the Quercus rise, ca. 300 - 365 years into the Eemian. Later, during the Corylus rise, ca. 650 years into Eemian, the water became more warm and saline. Almost full marine conditions had developed by ca. 2500 years (Kristensen et al., 2000; Head et al., 2001).

\section{Material and Methods}

Eight bulk samples were collected from the 'Freshwater sand' and the 'Cyprina clay' in thrust slice 12 (Fig. 2; Table 1). The samples consisted of hard, but uncemented sediment. Each sample was 16 litres in volume and subjected to a two-stage preparation, namely disaggregating and sieving. Following Wilson (1965) and Allman \& Lawrence (1972), the sample was dried in a ventilated oven at $80-90{ }^{\circ} \mathrm{C}$ for two days to remove all moisture, and then cooled to room temperature. The sample was covered with 'odourless' paraffin oil, equivalent to kerosene, for 24 hours. Afterward, the surplus paraffin oil was poured off, and the oil-saturated sample immersed in boiling water for a quarter of an hour, resulting in a fluid with disaggregated sediment. Anhydrous sodium carbonate was added to the water to ease disaggregation, $50 \mathrm{~g}$ per litre of water (Allman \& Lawrence, 1972). The fluid was wet sieved carefully through a mesh of $0.7 \mathrm{~mm}$, and sorted for identifiable shells. Two samples, 114-551 and 114-553, needed a second paraffin oil treatment; however, no additional shells were identified after the second treatment.
The bulk samples from the 'Cyprina clay' are characterized by highly fragmented shells, which are derived from an unknown number of individuals. Sample handling may have caused some fragmentation. The shells thus are counted semiquantitatively (Table 1).

Taphonomic features formed by abrasion, bioerosion, disarticulation, encrustation and fragmentation were examined for each individual shell under binocular microscope $(\times 40)$. Scanning electron microscopy (SEM) was conducted on a number of shells to recognize possibly occurring minute features such as microborings, and shell structures within the common species were identified following the terminology by Carter et al. (1990). Field observations on biofabric and taphonomic features were also carried out, leading to the collection of six hand-picked samples from shell-rich levels (Fig. 2; Table 2). The hand-picked samples provide more reliable numbers of shells, because the shells were counted before sampling. Manually removing shells from the clay allowed to combine fragments of glaciotectonically compacted specimens to be treated as a single specimen. Distinction between pre- and postdepositional fragmentation is only possible with shells still preserved within the sediment. Post-depositional fragmentation is recognized as fitting shell fragments preserved next to each other. Thus, bulk samples and hand-picked samples are complementary. The shell material studied is deposited in the Geological Museum, University of Copenhagen.

The preservation of individual shells was estimated with the three-level scheme of taphonomic grades by Kowalewski et

Table 1. Macrofauna in bulk samples. ${ }^{1}$

\begin{tabular}{|c|c|c|c|c|c|c|c|c|}
\hline Stratigraphical levels $(\mathrm{cm})$ & $244-232$ & $232-222$ & 202-192 & $182-172$ & $137-127$ & $92-82$ & $52-42$ & $10-0$ \\
\hline Samples (114-) & 550 & 551 & 552 & 553 & 554 & 555 & 556 & 570 \\
\hline \multicolumn{9}{|l|}{ Gastropoda } \\
\hline Gastropoda sp. indet. & & & & & $S$ & & S & $\mathrm{S}$ \\
\hline Bittium reticulatum (da Costa, 1778) & & & & S & C & 1 & & \\
\hline Hydrobia ulvae (Pennant, 1777) & & & & S & S & & & \\
\hline \multicolumn{9}{|l|}{ Nassarius reticulatus (Linné, 1758) } \\
\hline \multicolumn{9}{|l|}{ Bivalvia } \\
\hline Mytilus edulis Linné, 1758 & & & & $\mathrm{D}$ & D & $\mathrm{F}$ & 2 & \\
\hline Ostrea edulis Linné, 1758 & & & & & & S & $S^{2}$ & \\
\hline Acanthocardia echinata (Linné, 1758) & & & & & & $\mathrm{S}$ & $\mathrm{D}$ & S \\
\hline Cerastoderma edule (Linné, 1758) & & & & $\mathrm{F}$ & $\mathrm{F}$ & & & \\
\hline Spisula elliptica (Brown, 1827) & & & & & & 3 & & \\
\hline Arctica islandica (Linné, 1767) & & & & & & S & & S \\
\hline Paphia senescens (Cocconi, 1873) & & & & $\mathrm{D}$ & D & C & $\mathrm{F}$ & C \\
\hline Corbula gibba (Olivi, 1792) & & & & & & & $\mathrm{F}$ & S \\
\hline \multicolumn{9}{|l|}{ Cirripedia } \\
\hline Balanus improvisus Darwin, 1854 & & & & & S & C & & \\
\hline \multicolumn{9}{|l|}{ Trace fossils } \\
\hline \multicolumn{6}{|c|}{ Caulostrepsis taeniola Bromley and D'Alessandro, 1983} & & 1 & \\
\hline
\end{tabular}


(Kristensen et al., 2000). The marine transgression characterized by low salinity took place during the Quercus rise, ca. 300 - 365 years into the Eemian. Later, during the Corylus rise, ca. 650 years into Eemian, the water became more warm and saline. Almost full marine conditions had developed by ca. 2500 years (Kristensen et al., 2000; Head et al., 2001).

\section{Material and Methods}

Eight bulk samples were collected from the 'Freshwater sand' and the 'Cyprina clay' in thrust slice 12 (Fig. 2; Table 1). The samples consisted of hard, but uncemented sediment. Each sample was 16 litres in volume and subjected to a two-stage preparation, namely disaggregating and sieving. Following Wilson (1965) and Allman \& Lawrence (1972), the sample was dried in a ventilated oven at $80-90{ }^{\circ} \mathrm{C}$ for two days to remove all moisture, and then cooled to room temperature. The sample was covered with 'odourless' paraffin oil, equivalent to kerosene, for 24 hours. Afterward, the surplus paraffin oil was poured off, and the oil-saturated sample immersed in boiling water for a quarter of an hour, resulting in a fluid with disaggregated sediment. Anhydrous sodium carbonate was added to the water to ease disaggregation, $50 \mathrm{~g}$ per litre of water (Allman \& Lawrence, 1972). The fluid was wet sieved carefully through a mesh of $0.7 \mathrm{~mm}$, and sorted for identifiable shells. Two samples, 114-551 and 114-553, needed a second paraffin oil treatment; however, no additional shells were identified after the second treatment.
The bulk samples from the 'Cyprina clay' are characterized by highly fragmented shells, which are derived from an unknown number of individuals. Sample handling may have caused some fragmentation. The shells thus are counted semiquantitatively (Table 1).

Taphonomic features formed by abrasion, bioerosion, disarticulation, encrustation and fragmentation were examined for each individual shell under binocular microscope $(\times 40)$. Scanning electron microscopy (SEM) was conducted on a number of shells to recognize possibly occurring minute features such as microborings, and shell structures within the common species were identified following the terminology by Carter et al. (1990). Field observations on biofabric and taphonomic features were also carried out, leading to the collection of six hand-picked samples from shell-rich levels (Fig. 2; Table 2). The hand-picked samples provide more reliable numbers of shells, because the shells were counted before sampling. Manually removing shells from the clay allowed to combine fragments of glaciotectonically compacted specimens to be treated as a single specimen. Distinction between pre- and postdepositional fragmentation is only possible with shells still preserved within the sediment. Post-depositional fragmentation is recognized as fitting shell fragments preserved next to each other. Thus, bulk samples and hand-picked samples are complementary. The shell material studied is deposited in the Geological Museum, University of Copenhagen.

The preservation of individual shells was estimated with the three-level scheme of taphonomic grades by Kowalewski et

Table 1. Macrofauna in bulk samples. ${ }^{1}$

\begin{tabular}{|c|c|c|c|c|c|c|c|c|}
\hline \multirow{2}{*}{$\begin{array}{l}\text { Stratigraphical levels (cm) } \\
\text { Samples (114-) }\end{array}$} & $244-232$ & $232-222$ & 202-192 & $182-172$ & $137-127$ & $92-82$ & $52-42$ & $10-0$ \\
\hline & 550 & 551 & 552 & 553 & 554 & 555 & 556 & 570 \\
\hline \multicolumn{9}{|l|}{ Gastropoda } \\
\hline \multicolumn{2}{|l|}{ Gastropoda sp. indet. } & & & & S & & S & S \\
\hline \multicolumn{2}{|l|}{ Bittium reticulatum (da Costa, 1778) } & & & S & C & 1 & & \\
\hline \multicolumn{2}{|l|}{ Hydrobia ulvae (Pennant, 1777) } & & & S & S & & & \\
\hline \multicolumn{9}{|l|}{ Nassarius reticulatus (Linné, 1758) } \\
\hline \multicolumn{9}{|l|}{ Bivalvia } \\
\hline \multicolumn{2}{|l|}{ Mytilus edulis Linné, 1758} & & & D & $\mathrm{D}$ & F & 2 & \\
\hline \multicolumn{2}{|l|}{ Ostrea edulis Linné, 1758} & & & & & S & $S^{2}$ & \\
\hline \multicolumn{2}{|l|}{ Acanthocardia echinata (Linné, 1758) } & & & & & $S$ & $\mathrm{D}$ & S \\
\hline \multicolumn{2}{|l|}{ Cerastoderma edule (Linné, 1758) } & & & $\mathrm{F}$ & F & & & \\
\hline \multicolumn{2}{|l|}{ Spisula elliptica (Brown, 1827) } & & & & & 3 & & \\
\hline \multicolumn{2}{|l|}{ Arctica islandica (Linné, 1767) } & & & & & S & & S \\
\hline \multicolumn{2}{|l|}{ Paphia senescens (Cocconi, 1873) } & & & D & D & C & F & C \\
\hline \multicolumn{2}{|l|}{ Corbula gibba (Olivi, 1792) } & & & & & & $\mathrm{F}$ & $\mathrm{S}$ \\
\hline \multicolumn{9}{|l|}{ Cirripedia } \\
\hline \multicolumn{2}{|l|}{ Balanus improvisus Darwin, 1854} & & & & $\mathrm{~S}$ & C & & \\
\hline \multicolumn{9}{|l|}{ Trace fossils } \\
\hline \multicolumn{4}{|c|}{ Caulostrepsis taeniola Bromley and D'Alessandro, 1983} & & & & 1 & \\
\hline
\end{tabular}


al. (1995) and Hallman et al. (1996). Grades 0, 1 and 2 refer to no, moderate $(1-20 \%)$ and high alteration (>20\%), for all taphonomic features except fragmentation (>50\%). Biofabrics were described with the terminology of Kidwell \& Holland (1991).

\section{Results}

\section{Paleofauna}

Overall, bivalves and gastropods are common within the 'Cyprina clay' (Fig. 4; Table 1, 2); none were found in samples from the underlying freshwater layers. The prevalent mollusk species within the 'Cyprina clay' are Nassarius reticulatus (Gastropoda), Paphia senescens, Mytilus edulis and Corbula gibba (Bivalvia) (Fig. 4). The fauna in the lowermost part of the 'Cyprina clay' (interval from 232 to $187 \mathrm{~cm}$ ) is sparse and consists of a few unidentifiable fragments. Above this part, shell-rich horizons (interval from 187 to $120 \mathrm{~cm}$ ) are dominated by Mytilus edulis and Paphia senescens and to a lesser amount Cerastoderma edule and Nassarius reticulatus (Fig. 5). Bivalves are more common than gastropods. Between the shell-rich horizons, a few dispersed shells of Nassarius reticulatus and Paphia senescens occur (Fig. 4). Plates of Balanus improvisus occur sparsely. Although the barnacles may have lived on the shells, none of the barnacles have been observed as encrusters. The calcareous basal plates of $B$. improvisus, which usually are firmly attached to substrates, are absent from the shells. Above the shell-rich horizons, shells of Corbula gibba (interval

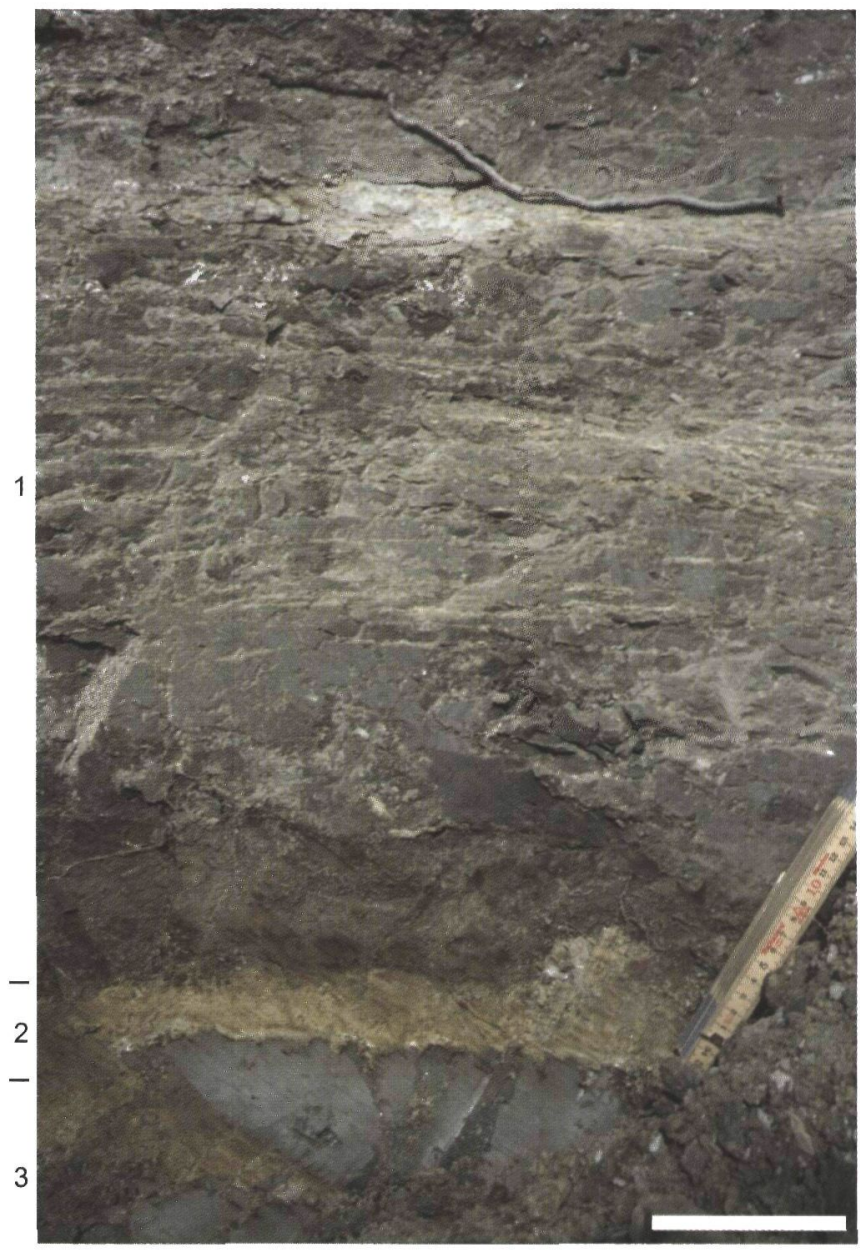

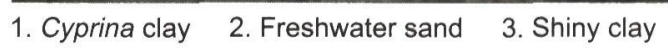

a.

Fig. 3. Eemian units within thrust slice no. 12; a. The 'Shiny clay' overlain by the 'Freshwater sand' and the 'Cyprina clay'. Note the lamination in the 'Cyprina clay'. Scale bar $10 \mathrm{~cm}$; $b$. Shellrich horizons (small arrows) in the 'Cyprina clay'. Note compacted nature of the fauna. Stratigraphic upward indicated by large

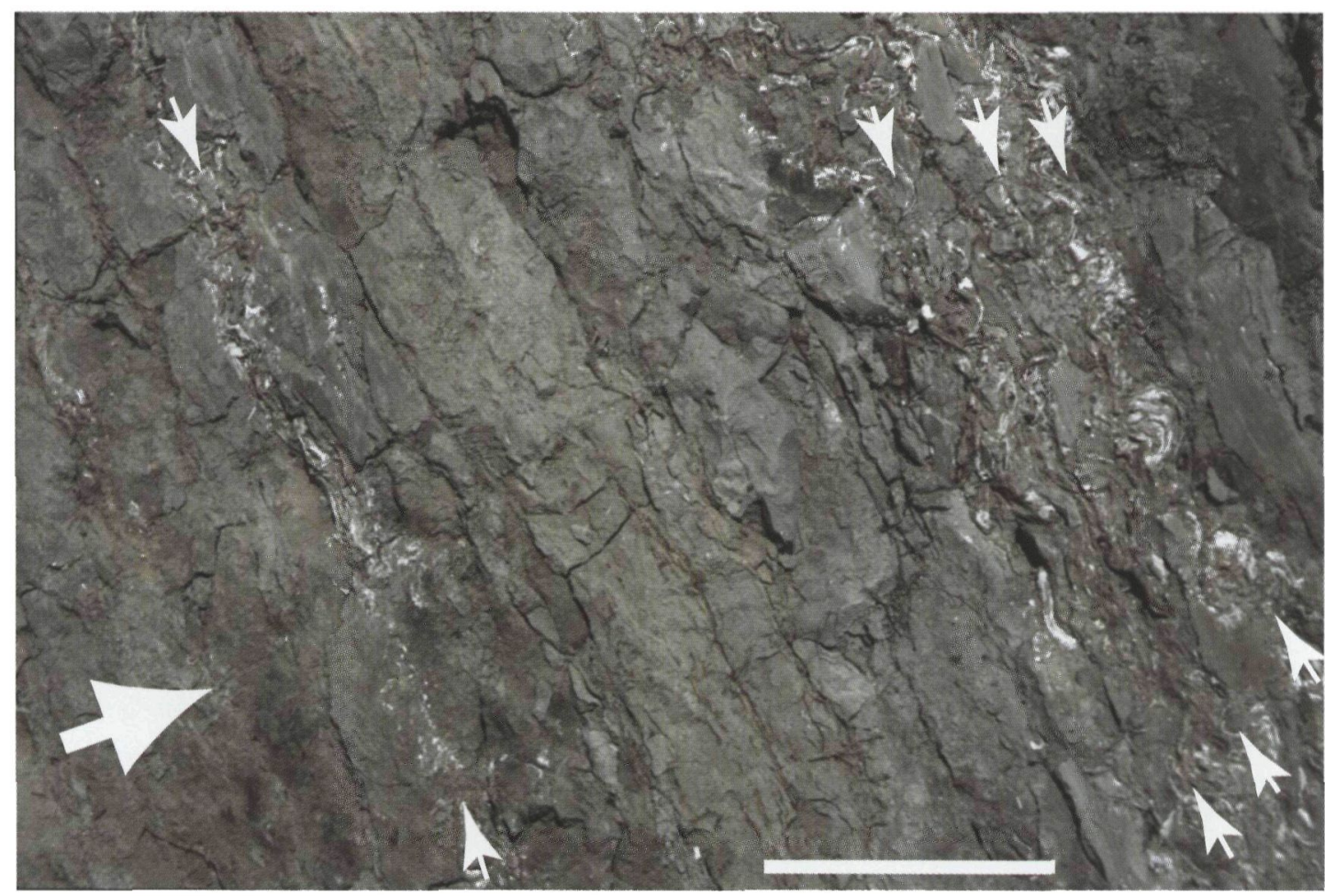
arrow. Scale bar $20 \mathrm{~cm}$. b. 
Table 2. Macrofauna in hand-picked samples. ${ }^{1}$

\begin{tabular}{|c|c|c|c|c|c|c|c|c|c|c|c|c|c|c|c|c|c|c|}
\hline Stratigraphic levels $(\mathrm{cm})$ & \multicolumn{2}{|c|}{ (shell lens) } & & \multicolumn{3}{|c|}{ (Horizon No. 1) } & (Hori & $\begin{array}{r}143 \\
\text { izon }\end{array}$ & No. 2) & \multicolumn{3}{|c|}{$\begin{array}{c}134 \\
\text { (Horizon No. 3) }\end{array}$} & \multicolumn{3}{|c|}{$\begin{array}{c}127 \\
\text { (Horizon No. 4) }\end{array}$} & \multicolumn{3}{|c|}{110} \\
\hline \multirow[t]{2}{*}{ Samples (114-) } & \multicolumn{3}{|c|}{569} & \multicolumn{3}{|c|}{564} & \multicolumn{3}{|c|}{565} & \multicolumn{3}{|c|}{$\frac{\text { (Horizon No. 3) }}{566}$} & \multicolumn{3}{|c|}{$\frac{\text { (Horizon No. 4) }}{567}$} & \multicolumn{3}{|c|}{568} \\
\hline & un & rag & frag & un & frag & frag & unf & frag & frag & \multicolumn{3}{|c|}{ unfrag frag } & \multicolumn{3}{|c|}{ unfrag $f$} & \multicolumn{2}{|c|}{ unfrag } & frag \\
\hline \multicolumn{19}{|l|}{ Gastropoda } \\
\hline Bittium reticulatum & & & & & & & & 1 & 2 & ( & 5 & 6 & 4 & & 6 & 1 & 1 & 2 \\
\hline Nassarius reticulatus & rv & lv & frag & rv & lv & frag & rv & lv & frag & rv & lv & frag & rv & lv & frag & rv & lv & frag \\
\hline \multicolumn{19}{|l|}{ Bivalvia } \\
\hline Mytilus edulis & & & 2 & 6 & 10 & 42 & 6 & 6 & 58 & 12 & 14 & 48 & 12 & 16 & 56 & & & 2 \\
\hline Cerastoderma edule & & & & & & 1 & & & & & & & & & 2 & & & \\
\hline Arctica islandica & & & & & & & & & & 2 & & & & & & & & \\
\hline Paphia senescens & & & & 8 & 6 & 28 & 4 & 1 & 12 & 2 & & 10 & & 4 & 2 & 4 & 4 & 12 \\
\hline Corbula gibba & & & & & & & & & & & & & & & & 28 & 27 & 10 \\
\hline Total number of identifiable shells & & 2 & & & 102 & & & 104 & & & 106 & & & 102 & & & 96 & \\
\hline
\end{tabular}

1 Identifiable valves and fragments in hand-picked samples by absolute number. Frag, fragmented; unfrag, unfragmented; rv, right valves; lv, left valves.
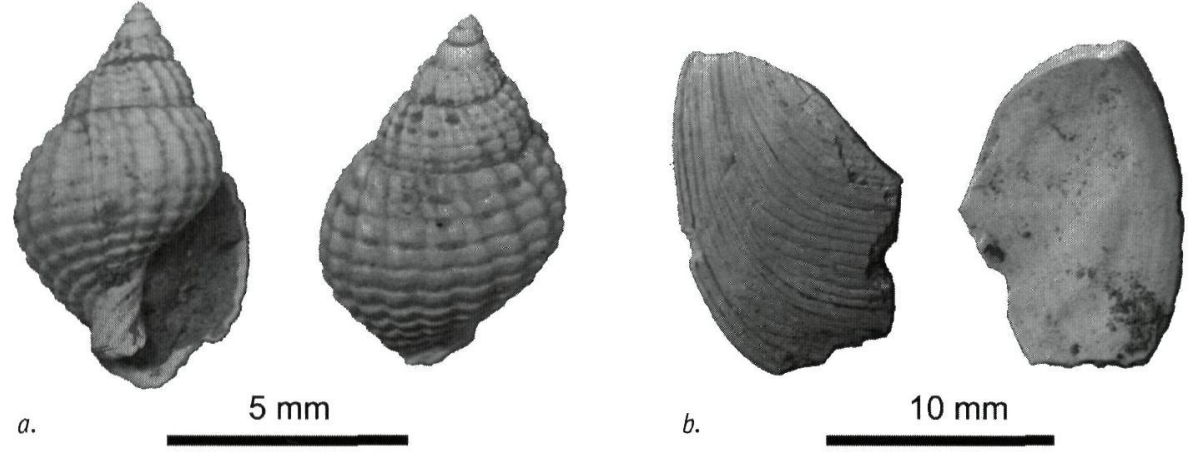

a.

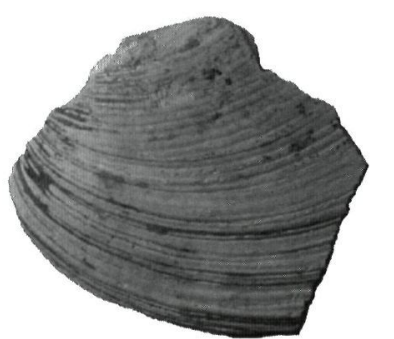

$5 \mathrm{~mm}$

c.

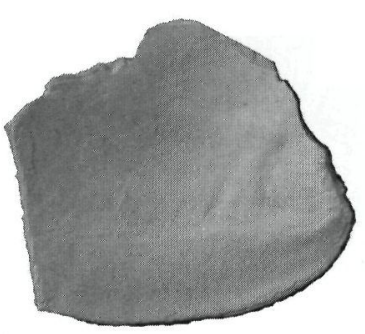

b.

d.
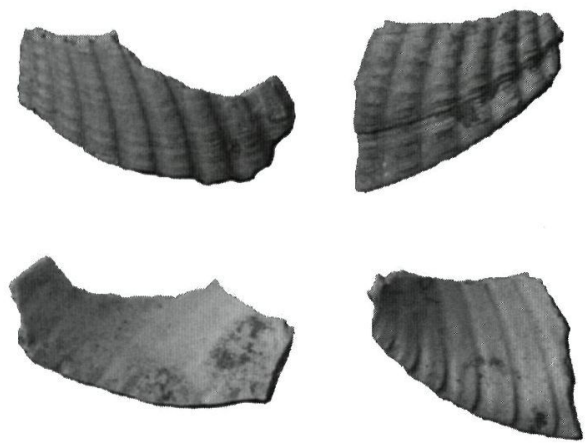

f. $5 \mathrm{~mm}$ g.

$5 \mathrm{~mm}$

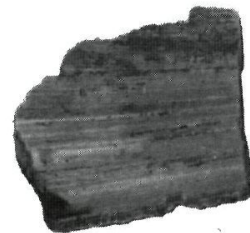

$5 \mathrm{~mm}$
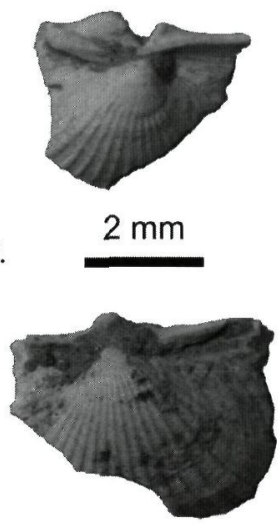

$10 \mathrm{~mm}$
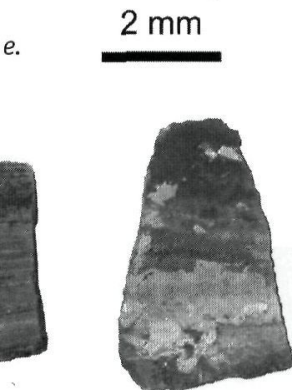

$5 \mathrm{~mm}$

Fig. 4. Common mollusk species in the 'Cyprina clay'; $a$. Nassarius reticulatus; $b$. Paphia senescens, posterior fragment of right valve; $c$. P. senescens, antero-ventral fragment of left valve; $d-g$. Cerastoderma edule, fragments of umbonal and marginal areas; $h-i$. Mytilus edulis, fragments of outer shell layer. All specimens from sample 114-553. 

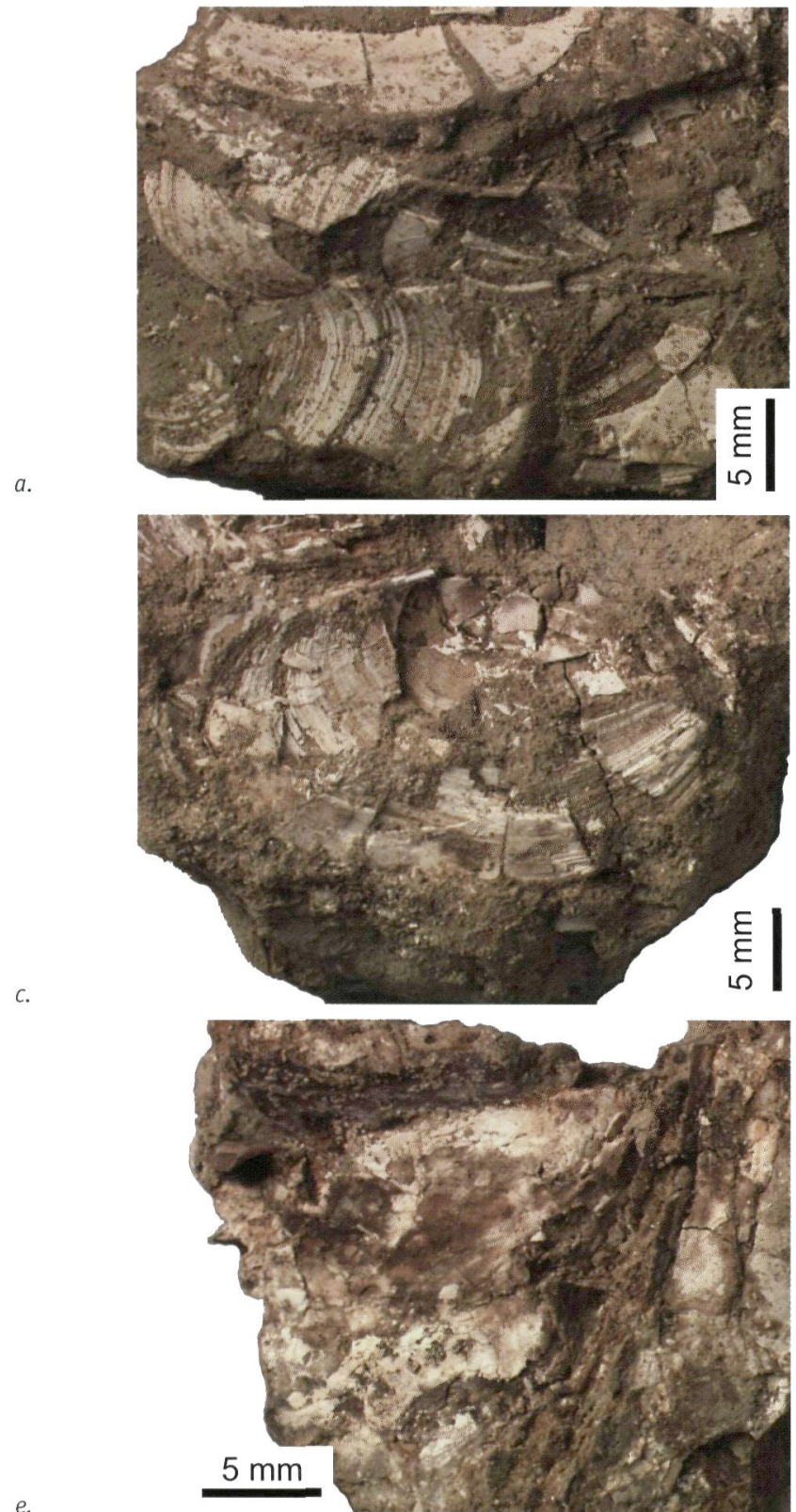

e.

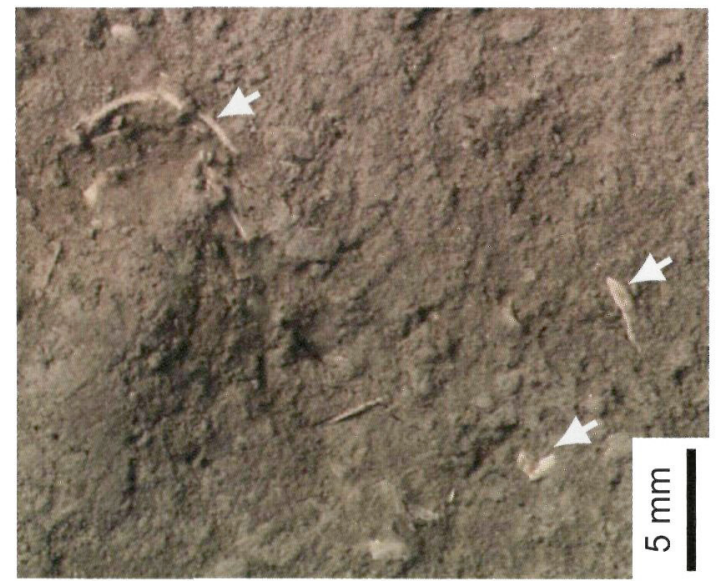

b.

d.

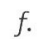

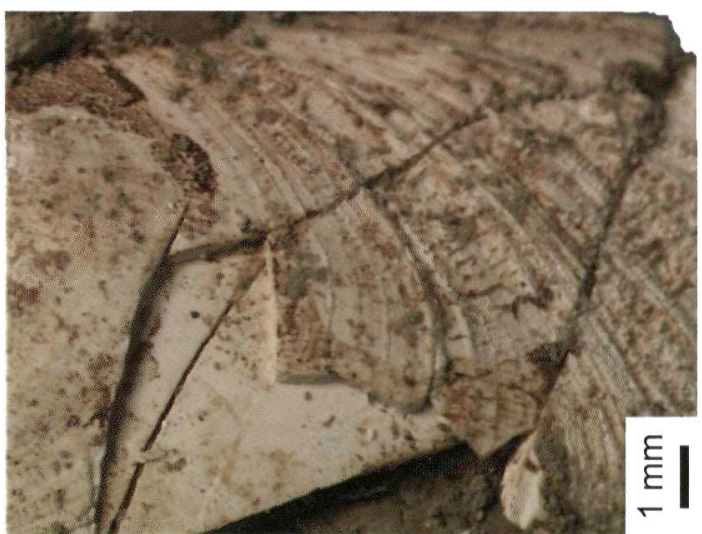
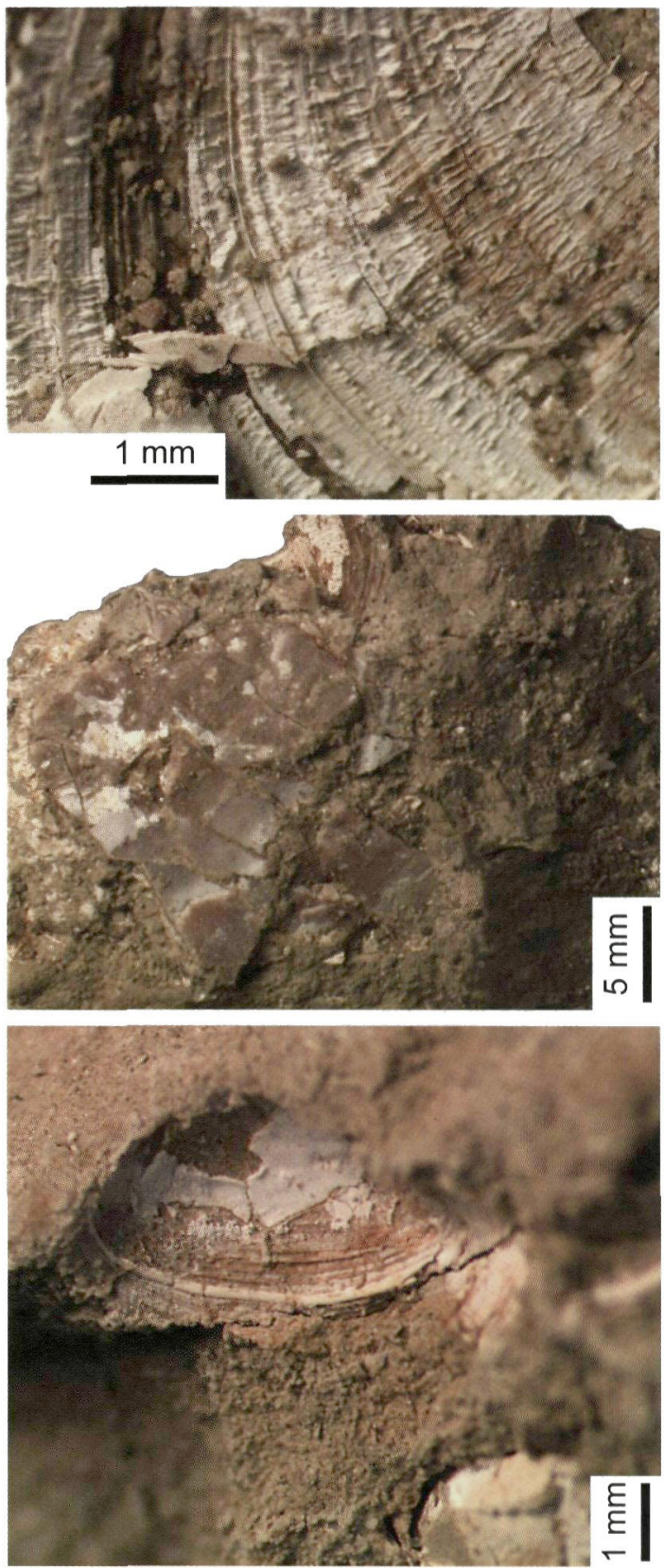

Fig. 5. Preservation of bivalves in shell-rich levels: a-f from sample 114-554 and $g$ - $h$ from sample 114-568; a. Paphia senescens, note the prevalent fragmentation of shells; $b$. P. senescens, the outer shell layer partly detached from the remaining shell; $c$. Fragments of single valve of $P$. senescens; d. Close-up showing dissolution texture of interior surface of the outer shell layer; e-f. Mytilus edulis, highly fragmented and dissolved; g. Dispersed shells (arrows) of Corbula gibba; $h$. Right valve of $\mathrm{C}$. gibba, a few remnants left after extensive dissolution. 
from 120 to $105 \mathrm{~cm}$ ) occur loosely dispersed in a $15 \mathrm{~cm}$ thick interval. These shells are followed by sparse occurrences of Paphia senescens, Corbula gibba and a few other mollusks (interval from 105 to $0 \mathrm{~cm}$ ). Plates of Balanus improvisus are common in the lower part of this latter interval. The fauna of mollusks and barnacles includes typical boreo-lusitanic species of coastal marine environments (e.g., Acanthocardia echinata, Balanus improvisus), suggesting relatively warmer water than in the present Baltic Sea. The fauna is comparable to faunas of the English Channel and southerly regions (Nordmann, 1908, 1928; see also Tebble, 1976).

\section{Shell structures}

The shell structures of the four most common species are described to recognize possible relationships between them and observed taphonomic features. As the descriptions may also be useful for future studies on taxonomy and shell structures, they are kept separately from the succeeding paragraphs on taphonomy.

\section{Nassarius reticulatus (Figure 6)}

The adult shell, i.e., the teleoconch whorls, is composed of three aragonitic shell layers. The inner and middle shell layers are of simple cross-lamellar structure, where length axes of the first-order lamellae composed of laths are perpendicular to the inner surface of the shell (Figs. 6a, b). Shapes of the firstorder lamellae are linear to slightly branching (Fig. 6c). The second-order laths are poorly defined. Their long axes are oriented parallel within each first-order lamella, and the intersection angle of the laths of adjacent first-order lamellae is about $100^{\circ}$. The laths consist of third-order rod-type crystallites. The inner and middle layers are separated by an $8 \mu \mathrm{m}$ thick interval of poorly developed crystallites (Fig. 6d).

The outer shell layer is of rod-type crossed lamellar structure with second-order structural units of ovoid rods (Figs. 6e, f). The first-order lamellae are oriented perpendicular to the middle layer, and outwardly inclined at an angle of 40 to $70^{\circ}$ to the shell axis in adapertural direction (Fig. 6b). The intersection angle of ovoid rods of neighbouring lamellae is measured as about $60^{\circ}$. The rods are tenth of $\mathrm{mm}$ in length and less than one $\mu \mathrm{m}$ in diameter.

\section{Paphia senescens (Figure 7)}

Three shell layers of aragonite are present (Fig. 7a). The inner and middle shell layers are made of fine complex crosslamellar structure (CCL), with some tendency towards a finegrained homogenous structure (Figs. 7b, c, d). The two layers are separated by pallial myostracum with irregular simple prisms (ISP) (Fig. 7e). Towards the outer shell layer, the middle shell layer shows a gradual transition to irregular anvil-type prisms
(Figs. 7f, g). Most of the prisms contain irregular prismatic subunits and resemble poorly developed aggregates of spherulitic structure (Figs. $7 \mathrm{~h}, \mathrm{i}, \mathrm{j}$ ). This transition is likely to have enclosed a greater proportion of intercrystalline and intracrystalline organic matter. Alemany (1987) recorded that recent specimens of Paphia aurea have a comparable transition, which is rich in organic matter.

The outer shell layer has a compound composite prismatic structure (CP) in which first-order composite prisms consist of numerous second-order composite prisms, which diverge away from the umbo in a feathery arrangement (Figs. 7b, h). In radial section, the first-order prisms are fusiform and are up to $500 \mu \mathrm{m}$ long and $50 \mu \mathrm{m}$ wide. An outer shell layer of a CP variety is typical for other species of the subfamily Tapetinae (family Veneridae), e.g., Paphia aurea, Paphia rhomboides and Venerupis decussata (Bøggild, 1930; Alemany, 1986, 1987; Rogalla \& Amler, 2003).

Spherulitic structure occurs sporadically in the outer shell layer, particularly close to the above-mentioned transition (Fig. 7j). Each spherulite is a spherical to subspherical aggregation of elongate structural subunits radiating in all directions from a nucleation site (Fig. 7j). Similar aggregations appear to be present in Paphia aurea (see Alemany, 1987, pl. 1, figs c-d) and Paphia rhomboides (see Alemany, 1986, pl. 2, fig. k).

\section{Mytilus edulis}

The shell is basically three-layered with aragonitic inner and middle layers and a calcitic outer layer. The inner and middle shell layers consist of sheet nacre and are separated by pallial myostracal aragonitic ISP. A few ISP sublayers are present in the inner shell layer. The outer shell layer is anvil-type to irregular, lath-type fibrous prismatic. Details of the structures were given by Carter (1990), Carter et al. (1990) and Nielsen (2004).

\section{Corbula gibba}

The shell is aragonitic and composed of two major shell layers. The inner shell layer consists of fine complex cross-lamellar structure (CCL) that is finely laminated. The laminae are about 2 - $3 \mu \mathrm{m}$ thick. The outer shell layer is made up of branching simple cross-lamellar structure (CL). The first-order lamellae consist of lath-shaped crystallites being up to $1 \mu \mathrm{m}$ in thickness and tenths of $\mu \mathrm{m}$ in length. In adjacent first-order lamellae, these crystallites are oriented in opposing direction; the intersection angle is about $115^{\circ}$ in radial section.

The outer and inner shell layers contain a thick and thin conchiolin layer, respectively. Calcareous cones, which are about $8 \mu \mathrm{m}$ in size, are interbedded in the conchiolin layers. The periostracum is brown (Taylor et al.,'1973; Lewy \& Samtleben, 1979; This study). Periostracal flaps and sheets may be incorporated into the shell (Taylor et al., 1973). 

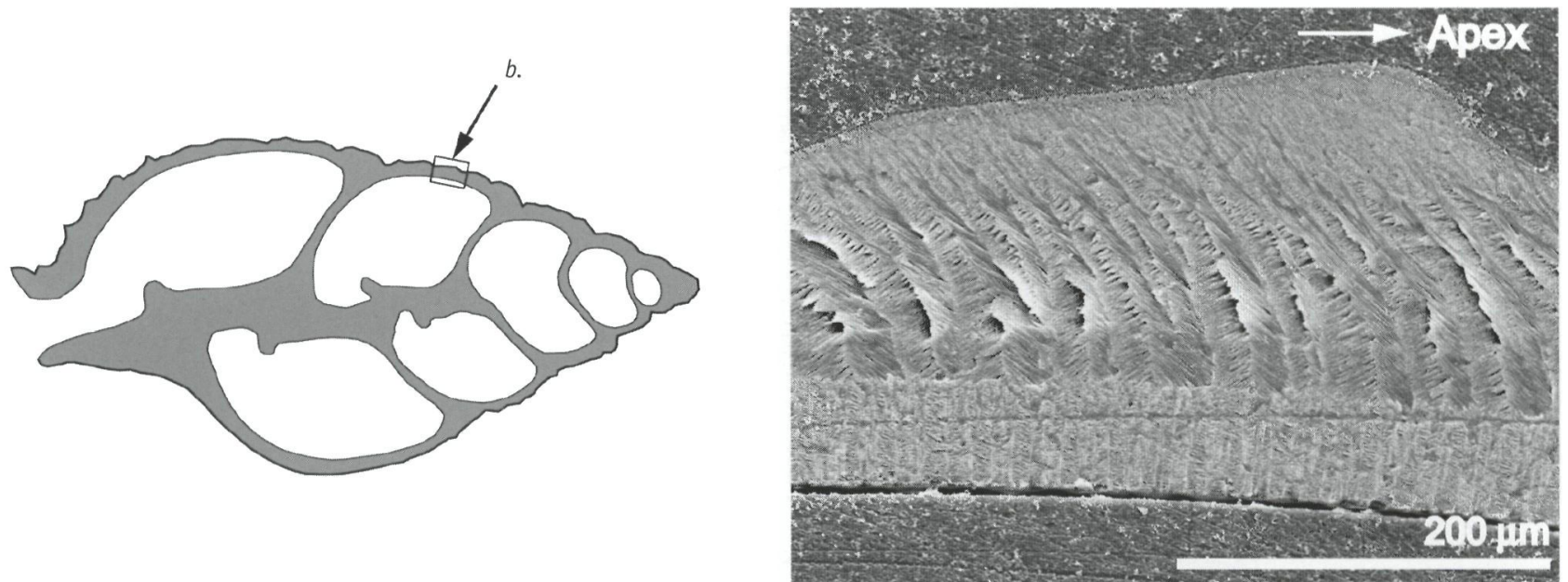

$a$.
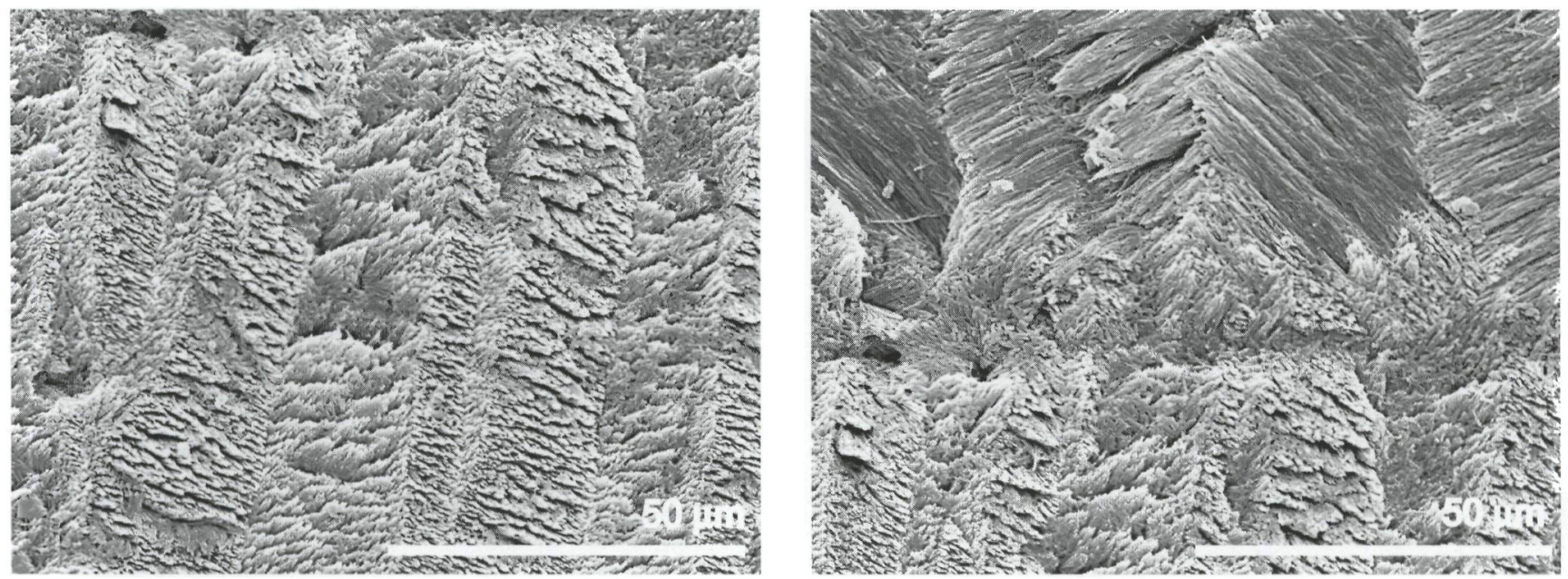

C.
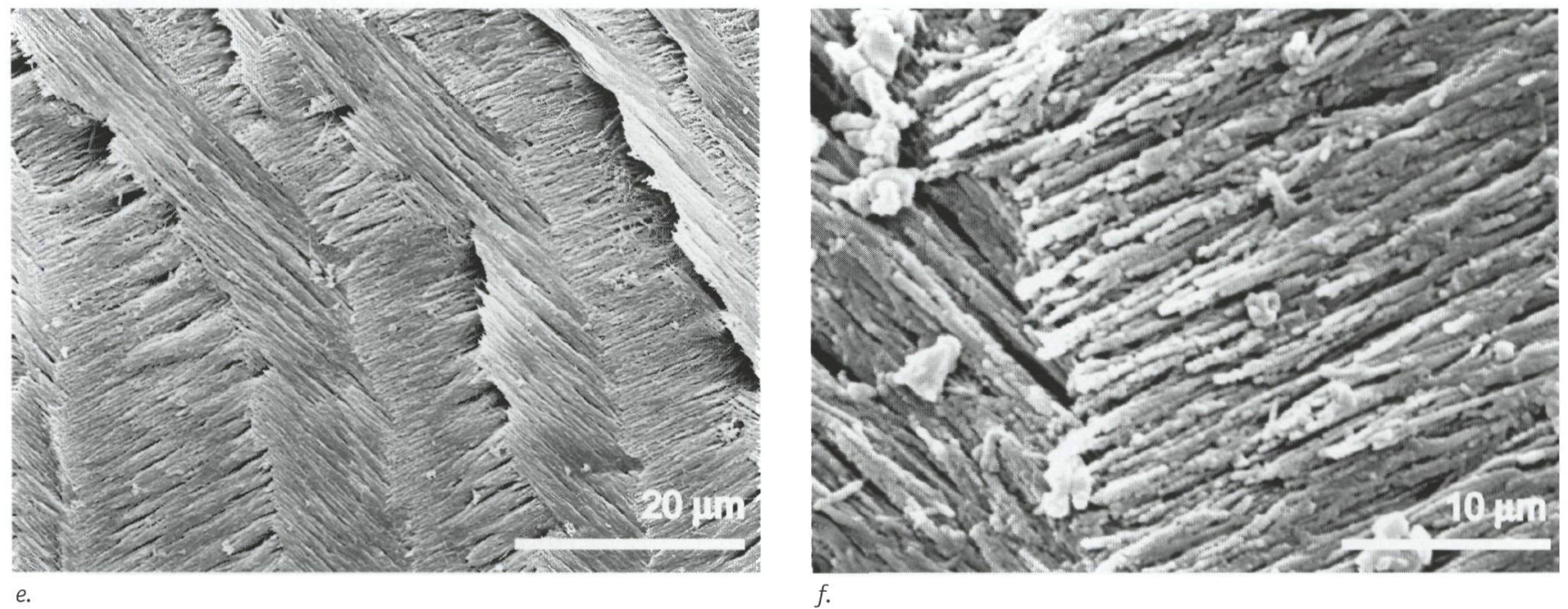

Fig. 6. Shell structures in Nassarius reticulatus (sample 114-553), shown in axial shell section; a. Sketch of apical-aperatural cross section; b. Cross-section of the inner and middle shell layers overlain by the outer shell layer. All shell layers with cross-lamellar structure; c. Close-up of first-order lamellae within the inner shell layer; $d$. The shell layers within the upper part of a whorl. The middle shell layer is very thin here. The inner shell layer is separated by an interval of poorly developed laths; e. First-order lamellae of the outer shell layer; $f$. Close-up of rod-type crystallites within these lamellae. 

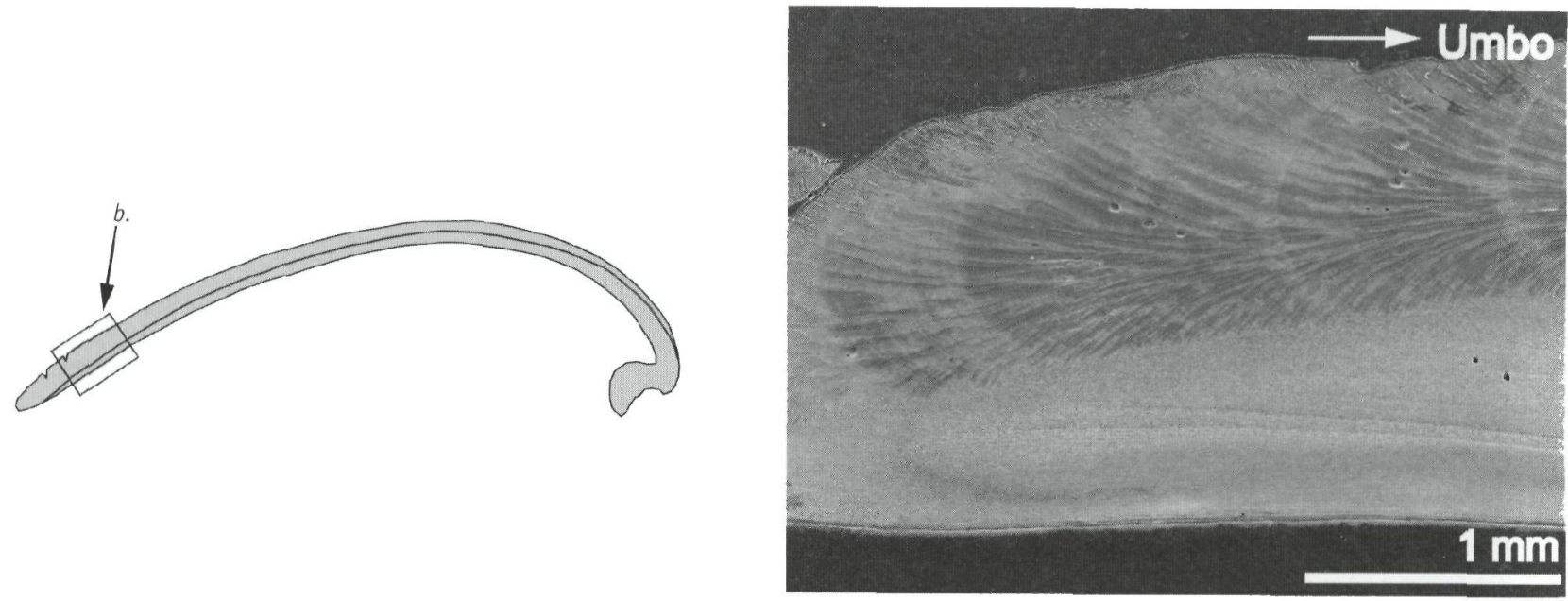

a.

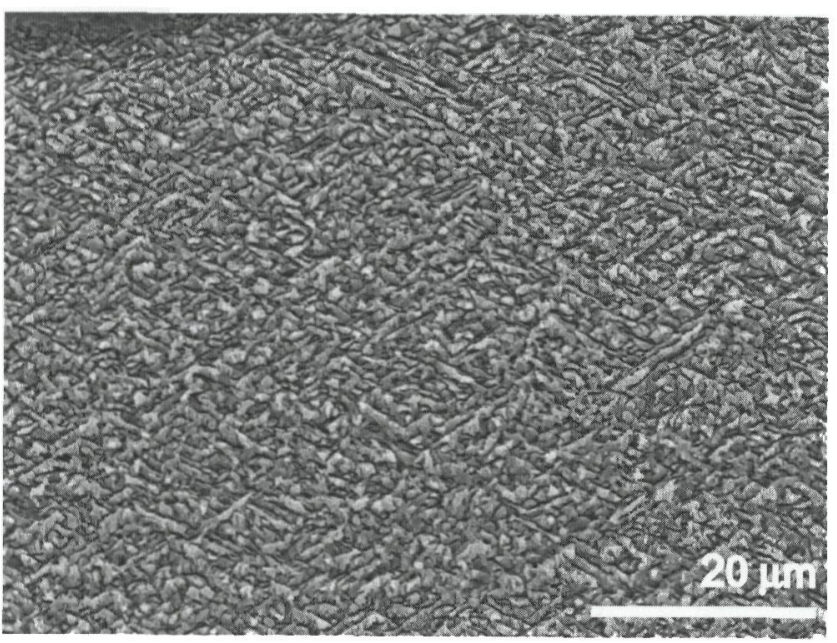

b.

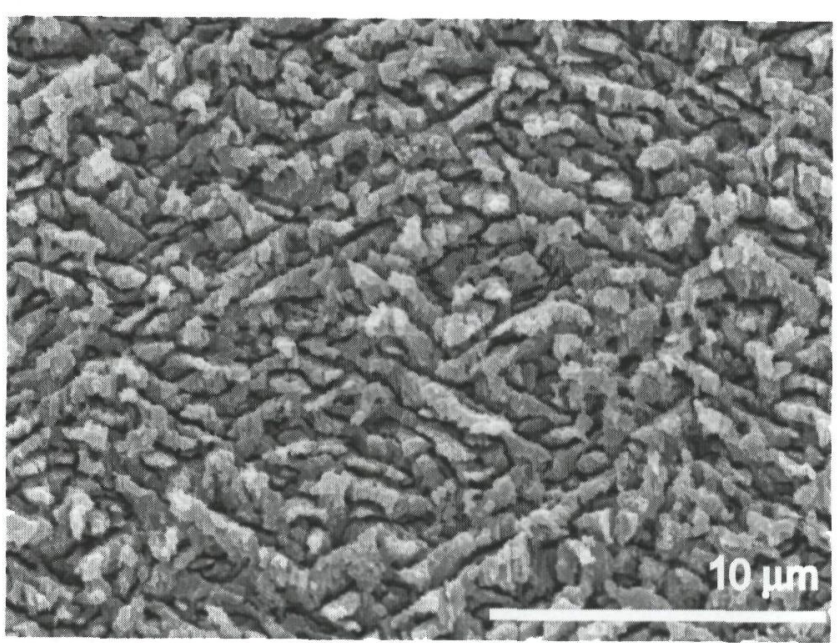
d.
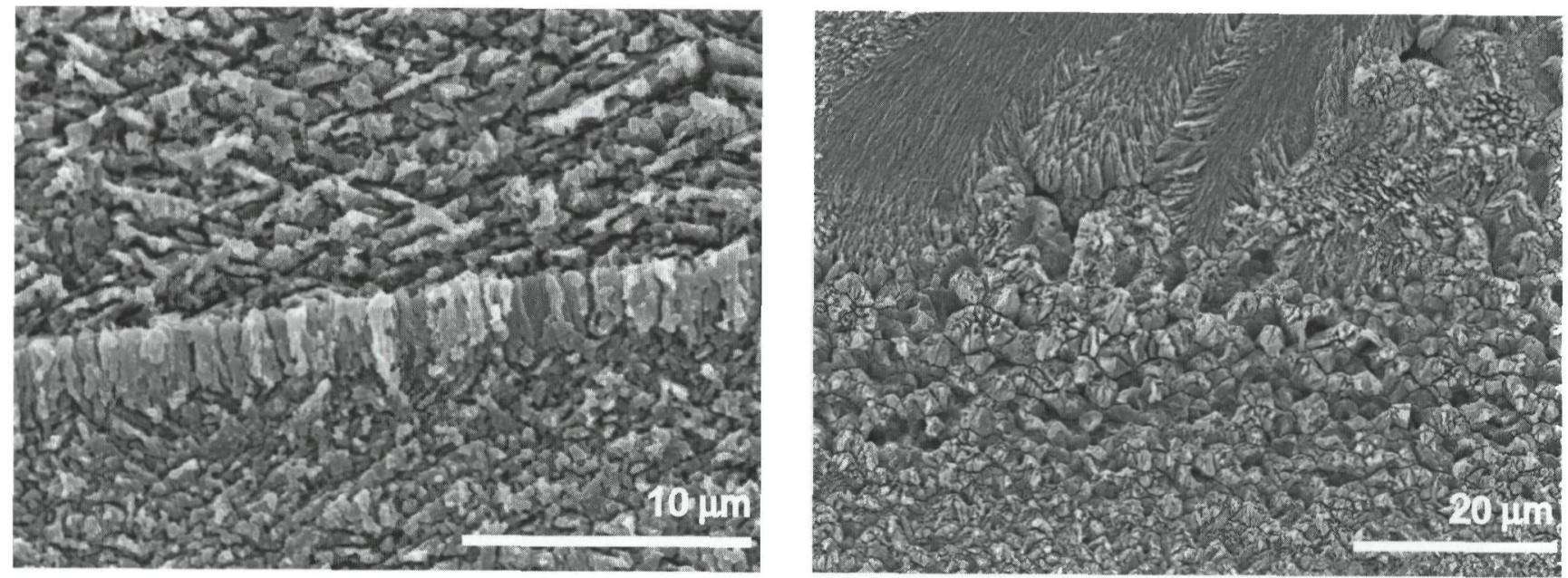

e.

$f$.

Fig. 7. Shell structures in Paphia senescens (sample 114-553), shown in radial shell section from umbo to ventral margin; a. Outlines of major shell layers; $b$. The inner shell layer overlain by the outer shell layer with first-order composite prisms in a feathery arrangement; $c$. The inner shell layer with complex cross-lamellar structure; $c$. Close-up of the same; e. Irregular simple prisms between the inner and middle shell layers; $f$. The outermost part of the middle shell layer overlain by the outer shell laye; $g$. Close-up of irregular anvil-type prisms in the outermost part of the middle shell layer; $h$. Firstorder composite prisms in the outer shell layer; $i$. Close-up of second-order composite prisms in the first-order composite prisms. A groove marks the boundary between the first-order composite prisms; $j$. Spherulite at the boundary between two first-order composite prisms of the outer shell layer. 


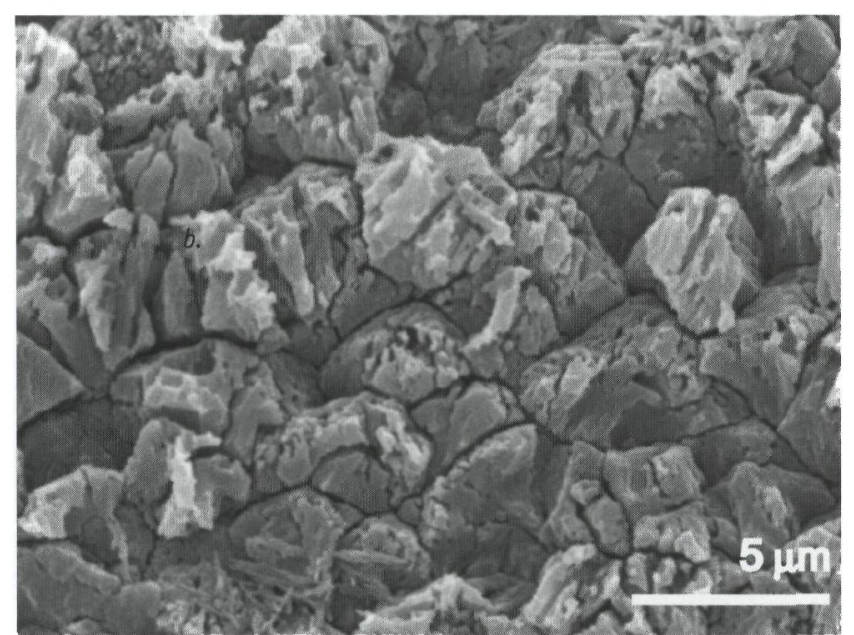

$g$.

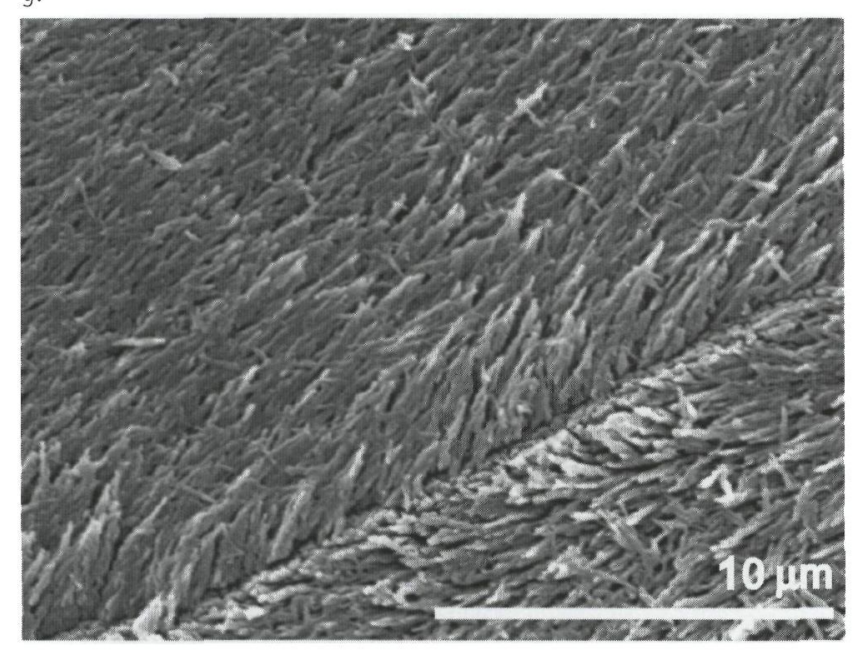

$i$.

\section{Taphonomy}

In general, the paleofaunas are characterized by crushed shells (Forchhammer, 1842). Glaciotectonic compaction in particular caused the extensive fragmentation (Nordmann, 1908). Four intervals (A - D) of distinct preservation states have been distinguished (Figs. 2, 8; Tables 3, 4). Taphonomic features, which formed before glacial compaction, are only used to independently validate and characterize these states of preservation.

Interval A $(232-187 \mathrm{~cm})$

\section{Description}

Mollusks in this interval are poorly preserved, i.e., the shells are disarticulated, highly fragmented and dissolved. The shell fragments are few and unidentifiable. They are less than $10 \mathrm{~mm}$ in size and loosely dispersed in the sediment. Encrustations and macroborings are absent. Some shell lenses of shell debris occur in the level 210 to $190 \mathrm{~cm}$. The lenses are less than $10 \mathrm{~cm}$ in lateral extension and $1 \mathrm{~cm}$ in thickness. The shell fragments are $\mathrm{mm}$ in size and well sorted, and they are generally oriented parallel to bedding. Some fragments of Mytilus edulis occur

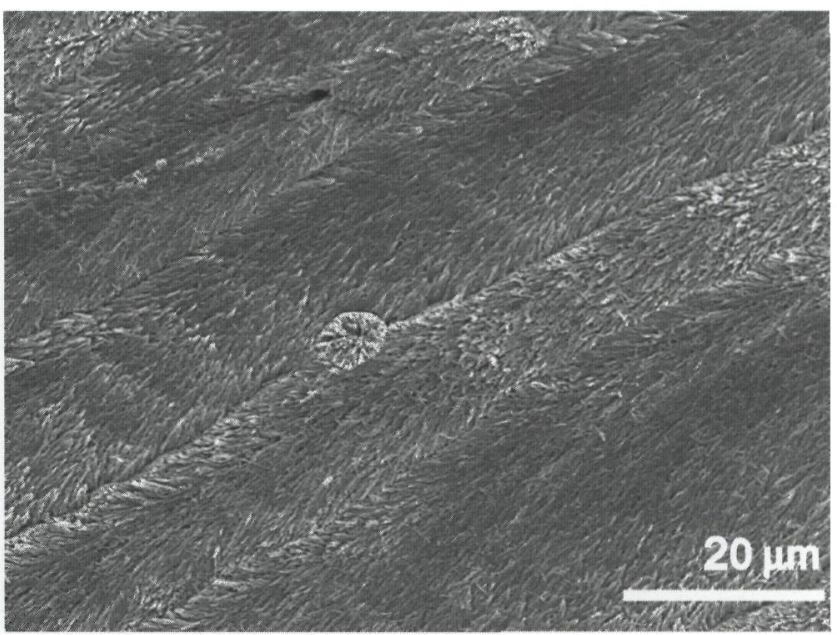

$h$.

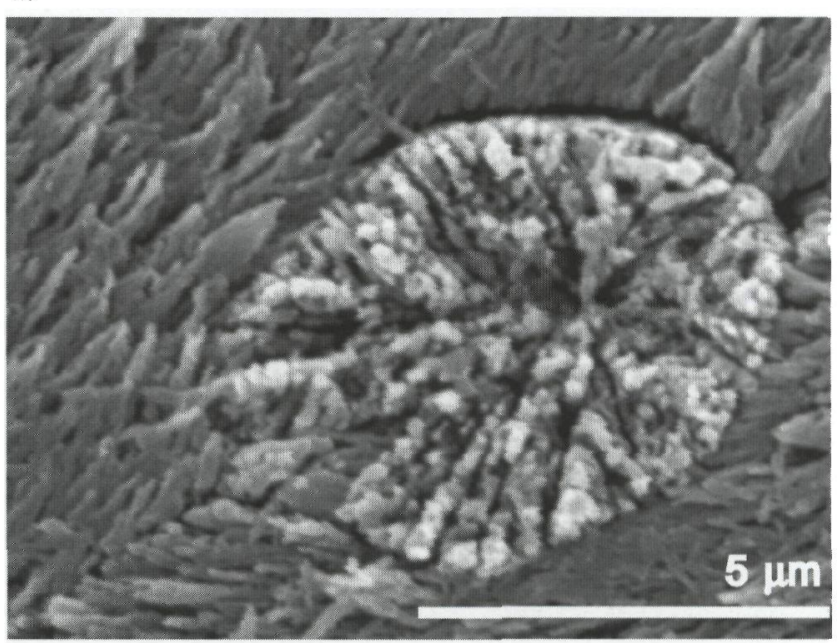

$j$.

within the lenses. The aragonitic nacre, which comprises the inner and middle shell layers, is commonly detached from the outer shell layer of calcitic fibrous prisms. The nacre appears to be most affected by dissolution, given rise to a white chalky appearance.

\section{Interpretation}

This interval is characterized by the worst state of mollusk preservation in the deposits studied. The disarticulation and fragmentation indicate that the dispersed shells were subjected to significant transport. Some fragmentation may be due to predation (e.g., Kidwell and Bosence, 1991; Cadée 1994; Zuschin et al. 2003). Bioturbational mixing is a less likely reason, because the sediment is laminated.

Taxonomic identification of shell debris is generally impossible, other than 'probably bivalve' (Banerjee and Kidwell, 1991). The presence of well-sorted shell debris in mud deficient in macrofossils implies transport by currents from another habitat. The shell debris may have formed as shell concentrations within 'gutter casts', common on storm-influenced muddy coasts. The high fragmentation indicates that the shells resided in an intervening environment and were reworked 


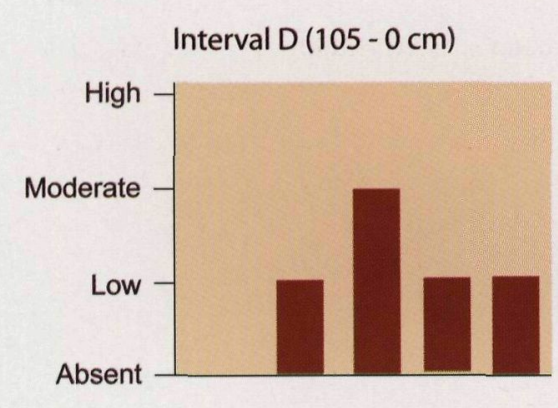

Interval C (120- $105 \mathrm{~cm})$

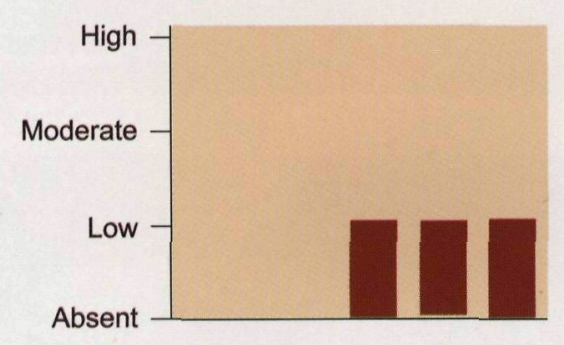

Interval B (187- $120 \mathrm{~cm})$

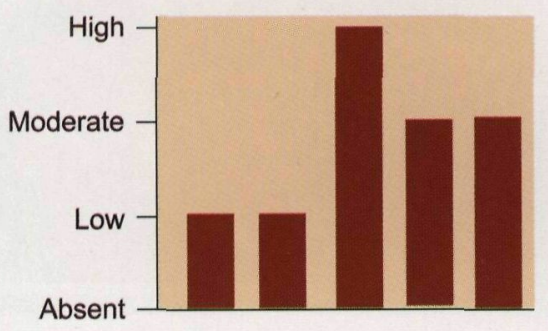

Interval A (232 - $187 \mathrm{~cm})$

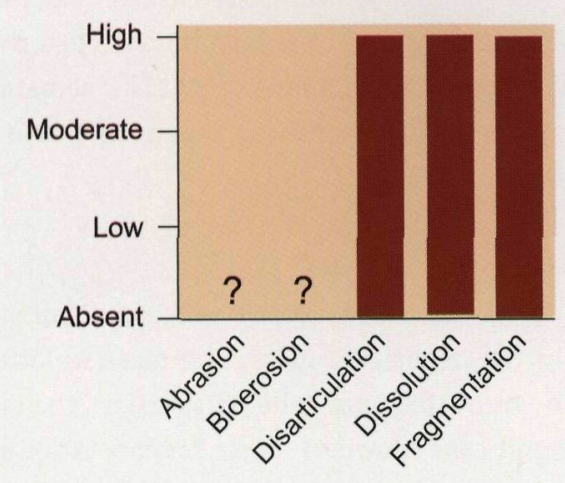

Fig. 8. Preservation of macrobenthic faunas in general.

before the final transport and deposition (Banerjee and Kidwell, 1991). The environment was characterized by highenergy conditions and may have been a shoreface or foreshore. These environments are common habitats of Mytilus edulis. If this was a muddy coast with shells concentrated in storm gutters, shells were possibly transported onshore, and then reworked as the storm surge drained. The final transport was probably in an offshore direction.
Interval B $(187-120 \mathrm{~cm})$

\section{Description}

This interval is characterized by well preserved shell remains that usually are smaller than $5 \mathrm{~cm}$. The shells are highly disarticulated and moderately fragmented and dissolved. Shell abrasion was also observed sparsely. Four loosely-packed, wellsorted shell-rich horizons (Nos 1 - 4 in Fig. 2) contain most of the shells present in this interval. The shells are preferentially oriented convex-up (60-75\%), whereas convex-down (25 - 40\%) shells are less common (Table 4). The horizons are less than $3.0 \mathrm{~cm}$ in thickness and at least up to tens of meters in lateral extension, and they may be capped by a normal-graded silty layer. Horizons 2 and 4 are laterally discontinuous.

Shells of various species differ in preservation. Small gastropods are typically better preserved than larger ones. The gastropods are up to $1.5 \mathrm{~cm}$ in length, while the bivalves are up to $5 \mathrm{~cm}$, typically 2 to $3 \mathrm{~cm}$ in length. Fragmentation is common and extensive for larger shells. Gastropods are generally less fragmented. Only a small proportion of Mytilus edulis shells obtained from the horizons are microscopically bioeroded to a moderate grade. None of the shells are encrusted. Clasts of sand and fine-grained gravel fractions occur mixed with the shells. A few shells of Nassarius reticulatus and Paphia senescens occur dispersed between the shell-rich horizons. The shells are fairly well preserved by being moderately fragmented and dissolved. The bivalves are predominately disarticulated.

Shell layers within an individual shell are differentially preserved. In general, the juvenile whorls of Nassarius reticulatus are typically gone. Within the teleoconch whorls, the outer shell layer of rod-type crossed lamellar structure (CL) has been more subjected to dissolution than the middle and inner shell layers of simple cross-lamellar structure (CL). Apertural margin of Nassarius reticulatus is commonly broken off. Fractures tend to follow the course of the first-order lamellae of the shell layers. All shell layers of Paphia senescens consist of aragonite. However, the outer shell layer of Paphia senescens is more dissolved than the middle and inner shells layers. This may be caused by differences in shell structures, i.e., the outer shell layer of compound composite prisms (CP) is less resistant than the middle and inner shell layers of fine complex cross-lamellae (CCL). The dissolution, which also may remove the irregular simple prisms (ISP) between the inner and middle shell layers, may lead to the separation of these two shell layers. The inner and middle shell layers of Mytilus edulis, which consist of sheet nacreous aragonite, are typically more affected by dissolution and detachment than the outer shell layer of calcitic prisms. The shell structure and mineralogy may have caused the differential dissolution. The outline of shell fragments reflects the structure of the outer shell layer. The fractures tend to follow the course of the large crystallites, i.e., calcitic prisms. 


\section{Interpretation}

Nordmann (1908) recognized two shell-rich horizons being laterally continuous. These correspond to the first and third horizon in the present study. The other two horizons, which are discontinuous, are previously unrecognized. The four horizons are very thin and graded, suggesting rapid redeposition from turbulent, probably storm-induced transport. Predominant convex-up attitudes of concavo-convex shells within shell beds suggest syndepositional reworking during storm events. The convex-up orientation is probably a result of reorientation by

Table 3. Shell preservation in hand-picked samples.

\begin{tabular}{|c|c|c|c|c|c|c|c|c|c|c|c|c|c|c|c|c|c|c|c|}
\hline \multicolumn{2}{|c|}{ Stratigraphic levels (cm) } & \multicolumn{3}{|c|}{$\begin{array}{c}195 \\
\text { (shell lens) }\end{array}$} & \multicolumn{3}{|c|}{$\begin{array}{c}181 \\
\text { (Horizon No. 1) } \\
\end{array}$} & \multicolumn{3}{|c|}{$\begin{array}{c}143 \\
\text { (Horizon No. 2) } \\
\end{array}$} & \multicolumn{3}{|c|}{$\begin{array}{c}134 \\
\text { (Horizon No. 3) } \\
\end{array}$} & \multicolumn{3}{|c|}{$\begin{array}{c}127 \\
\text { (Horizon No. 4) } \\
\end{array}$} & \multicolumn{3}{|c|}{110} \\
\hline \multicolumn{2}{|l|}{ Samples (114-) } & \multicolumn{3}{|c|}{569} & \multicolumn{3}{|c|}{564} & \multicolumn{3}{|c|}{565} & \multicolumn{3}{|c|}{566} & \multicolumn{3}{|c|}{567} & \multicolumn{3}{|c|}{568} \\
\hline Taphonomic grades & & 0 & 1 & 2 & 0 & 1 & 2 & 0 & 1 & 2 & 0 & 1 & 2 & 0 & 1 & 2 & 0 & 1 & 2 \\
\hline \multicolumn{20}{|l|}{ Gastropoda } \\
\hline \multirow[t]{5}{*}{ Bittium reticulatum } & Abrasion & 0 & 0 & 0 & 0 & 0 & 0 & 3 & 0 & 0 & 10 & 2 & 0 & 9 & 1 & 0 & 3 & 0 & 0 \\
\hline & Bioerosion & 0 & 0 & 0 & 0 & 0 & 0 & 3 & 0 & 0 & 12 & 0 & 0 & 10 & 0 & 0 & 3 & 0 & 0 \\
\hline & Dissolution & 0 & 0 & 0 & 0 & 0 & 0 & 1 & 2 & 0 & 6 & 6 & 0 & 2 & 6 & 2 & 0 & 3 & 0 \\
\hline & Fragmentation & 0 & 0 & 0 & 0 & 0 & 0 & 1 & 2 & 0 & 6 & 6 & 0 & 4 & 2 & 4 & 1 & 1 & 1 \\
\hline & Periostracum & 0 & 0 & 0 & 0 & 0 & 0 & 0 & 0 & 3 & 0 & 0 & 12 & 0 & 0 & 10 & 0 & 0 & 2 \\
\hline \multirow[t]{5}{*}{ Nassarius reticulatus } & Abrasion & 0 & 0 & 0 & 1 & 0 & 0 & 12 & 2 & 0 & 6 & 0 & 0 & 0 & 0 & 0 & 6 & 0 & 0 \\
\hline & Bioerosion & 0 & 0 & 0 & 1 & 0 & 0 & 14 & 0 & 0 & 6 & 0 & 0 & 0 & 0 & 0 & 6 & 0 & 0 \\
\hline & Dissolution & 0 & 0 & 0 & 0 & 1 & 0 & 10 & 4 & 0 & 4 & 2 & 0 & 0 & 0 & 0 & 2. & 2 & 2 \\
\hline & Fragmentation & 0 & 0 & 0 & 1 & 0 & 0 & 6 & 8 & 0 & 4 & 2 & 0 & 0 & 0 & 0 & 4 & 2 & 0 \\
\hline & Periostracum & 0 & 0 & 0 & 0 & 0 & 1 & 0 & 0 & 14 & 0 & 0 & 6 & 0 & 0 & 0 & 0 & 0 & 6 \\
\hline Bivalvia & & & & & & & & & & & & & & & & & & & \\
\hline Mytilus edulis & Abrasion & 1 & 1 & 0 & 54 & 4 & 0 & 68 & 2 & 0 & 69 & 5 & 0 & 78 & 6 & 0 & 2 & 0 & 0 \\
\hline & Bioerosion & 2 & 0 & 0 & 53 & 5 & 0 & 57 & 13 & 0 & 68 & 6 & 0 & 74 & 10 & 0 & 2 & 0 & 0 \\
\hline & Disarticulation & 0 & 2 & & 18 & 40 & & 14 & 56 & & 22 & 52 & & 28 & 56 & & 0 & 2 & \\
\hline & Dissolution & 0 & 1 & 1 & 4 & 13 & 41 & 7 & 30 & 33 & 4 & 27 & 43 & 12 & 26 & 46 & 0 & 0 & 2 \\
\hline & Fragmentation & 0 & 0 & 2 & 11 & 27 & 20 & 5 & 35 & 30 & 7 & 22 & 45 & 13 & 20 & 51 & 0 & 0 & 2 \\
\hline & Periostracum & 0 & 0 & 2 & 0 & 19 & 39 & 0 & 9 & 61 & 0 & 12 & 62 & 0 & 9 & 75 & 0 & 0 & 2 \\
\hline Cerastoderma edule & Abrasion & 0 & 0 & 0 & 0 & 1 & 0 & 0 & 0 & 0 & 0 & 0 & 0 & 1 & 1 & 0 & 0 & 0 & 0 \\
\hline & Bioerosion & 0 & 0 & 0 & 1 & 0 & 0 & 0 & 0 & 0 & 0 & 0 & 0 & 2 & 0 & 0 & 0 & 0 & 0 \\
\hline & Disarticulation & 0 & 0 & & 0 & 1 & & 0 & 0 & & 0 & 0 & & 0 & 2 & & 0 & 0 & \\
\hline & Dissolution & 0 & 0 & 0 & 1 & 0 & 0 & 0 & 0 & 0 & 0 & 0 & 0 & 1 & 1 & 0 & 0 & 0 & 0 \\
\hline & Fragmentation & 0 & 0 & 0 & 0 & 1 & 0 & 0 & 0 & 0 & 0 & 0 & 0 & 0 & 2 & 0 & 0 & 0 & 0 \\
\hline & Periostracum & 0 & 0 & 0 & 0 & 0 & 1 & 0 & 0 & 0 & 0 & 0 & 0 & 0 & 0 & 2 & 0 & 0 & 0 \\
\hline Arctica islandica & Abrasion & 0 & 0 & 0 & 0 & 0 & 0 & 0 & 0 & 0 & 1 & 1 & 0 & 0 & 0 & 0 & 0 & 0 & 0 \\
\hline & Bioerosion & 0 & 0 & 0 & 0 & 0 & 0 & 0 & 0 & 0 & 2 & 0 & 0 & 0 & 0 & 0 & 0 & 0 & 0 \\
\hline & Disarticulation & 0 & 0 & & 0 & 0 & & 0 & 0 & & 0 & 2 & & 0 & 0 & & 0 & 0 & \\
\hline & Dissolution & 0 & 0 & 0 & 0 & 0 & 0 & 0 & 0 & 0 & 0 & 2 & 0 & 0 & 0 & 0 & 0 & 0 & 0 \\
\hline & Fragmentation & 0 & 0 & 0 & 0 & 0 & 0 & 0 & 0 & 0 & 2 & 0 & 0 & 0 & 0 & 0 & 0 & 0 & 0 \\
\hline & Periostracum & 0 & 0 & 0 & 0 & 0 & 0 & 0 & 0 & 0 & 0 & 0 & 2 & 0 & 0 & 0 & 0 & 0 & 0 \\
\hline Paphia senescens & Abrasion & 0 & 0 & 0 & 35 & 7 & 0 & 14 & 3 & 0 & 10 & 2 & 0 & 6 & 0 & 0 & 15 & 2 & 3 \\
\hline & Bioerosion & 0 & 0 & 0 & 42 & 0 & 0 & 17 & 0 & 0 & 12 & 0 & 0 & 6 & 0 & 0 & 20 & 0 & 0 \\
\hline & Disarticulation & 0 & 0 & & 13 & 29 & & 4 & 13 & & 2 & 10 & & 4 & 2 & & 4 & 16 & \\
\hline & Dissolution & 0 & 0 & 0 & 22 & 16 & 4 & 5 & 9 & 3 & 4 & 6 & 2 & 2 & 4 & 0 & 5 & 10 & 5 \\
\hline & Fragmentation & 0 & 0 & 0 & 14 & 24 & 4 & 5 & 12 & 0 & 2 & 10 & 0 & 3 & 2 & 1 & 4 & 12 & 4 \\
\hline & Periostracum & 0 & 0 & 0 & 6 & 14 & 22 & 4 & 3 & 10 & 0 & 2 & 10 & 0 & 4 & 2 & 2 & 4 & 14 \\
\hline Corbula gibba & Abrasion & 0 & 0 & 0 & 0 & 0 & 0 & 0 & 0 & 0 & 0 & 0 & 0 & 0 & 0 & 0 & 65 & 0 & 0 \\
\hline & Bioerosion & 0 & 0 & 0 & 0 & 0 & 0 & 0 & 0 & 0 & 0 & 0 & 0 & 0 & 0 & 0 & 65 & 0 & 0 \\
\hline & Disarticulation & 0 & 0 & & 0 & 0 & & 0 & 0 & & 0 & 0 & & 0 & 0 & & 42 & 23 & \\
\hline & Dissolution & 0 & 0 & 0 & 0 & 0 & 0 & 0 & 0 & 0 & 0 & 0 & 0 & 0 & 0 & 0 & 18 & 36 & 11 \\
\hline & Fragmentation & 0 & 0 & 0 & 0 & 0 & 0 & 0 & 0 & 0 & 0 & 0 & 0 & 0 & 0 & 0 & 51 & 14 & 0 \\
\hline & Periostracum & 0 & 0 & 0 & 0 & 0 & 0 & 0 & 0 & 0 & 0 & 0 & 0 & 0 & 0 & 0 & 8 & 33 & 24 \\
\hline
\end{tabular}


Table 4. Orientation of hand-picked shells in the shell-rich horizons, referring to the orientation of bedding planes.

\begin{tabular}{|c|c|c|c|c|}
\hline Stratigraphic levels $(\mathrm{cm})$ & Horizon No. 1 & Horizon No. 2 & Horizon No. 3 & Horizon No. 4 \\
\hline Samples (114-) & 564 & 565 & 566 & 567 \\
\hline Convex-up & $60 \%$ & $64 \%$ & $75 \%$ & $63 \%$ \\
\hline \multirow[t]{2}{*}{ Convex-down } & $40 \%$ & $36 \%$ & $25 \%$ & $37 \%$ \\
\hline & $\mathrm{N}=98$ & $\mathrm{~N}=81$ & $\mathrm{~N}=80$ & $\mathrm{~N}=88$ \\
\hline
\end{tabular}

currents on a high-friction sediment surface (Richter, 1942; Johnson, 1957; Futterer, 1978a). The convex-up orientation is more stable than convex-down (Emery, 1968; Salazar-Jimenez et al., 1982). Both concordant and convex-down oriented shells, however, may have been redeposited out of suspension associated with turbulent storm currents (Futterer, 1978b; Allen, 1984; Kidwell \& Bosence, 1991). The ligament plays an important role in holding together the pairs of valves and opening them. As the valves commonly are preserved widely open, and even separated, the bivalves must have died before final deposition. The high grade of disarticulation is consistent with winnowing while the shells became reworked. Neither cross-cutting relations between the horizons, nor accretions into thicker accumulations have been observed in the present study. The sedimentary grading and shell orientation provide the only evidence for storm reworking of the seafloor in this muddy facies.

Differential preservation of shells is seen within various species as well as individual layers within shells (e.g., Nielsen, 2004). This is particularly apparent in shells of Mytilus edulis, which probably is related to mineralogical and structural differences of the shell layers. Although shells of Nassarius reticulatus and Paphia senescens consist entirely of aragonite, their shell layers are differentially affected by dissolution. Splitting of the shell layers, however, may be related not only to dissolution but also decay of organic matrix between these layers. Some of the shell structures appear to be characterized by higher permeability, which could have caused a relatively high flow of acidic porewater through certain shell layers.

Interval C $(120-105 \mathrm{~cm})$

\section{Description}

Corbula gibba shells less than $7 \mathrm{~mm}$ in length are abundant in this interval. These are loosely dispersed and apparently randomly oriented. Many of the Corbula gibba shells are still articulated, where the two valves are closed or gape slightly. Widely open shells are uncommon, and fragmentation is low. The shells are moderately to highly dissolved, while they are neither bioeroded nor encrusted. Periostracal remains are rare. In addition, poorly preserved indeterminate shell fragments occur sporadically. These mm-sized fragments are strongly dissolved. Both the inner shell layer (fine complex cross-lamellar structure) and outer shell layer (branching simple cross-lamellar structure) appear to be equally affected by dissolution.

\section{Interpretation}

The shells are well preserved, i.e., characterized by low fragmentation and disarticulation and without abrasion, indicating them to be preserved within-habitat in an offshore environment. The substrate preference of Corbula gibba, i.e., muddy sediment containing gravel clasts or biogenic fragments (Yonge, 1946; Tebble, 1976; Lewy \& Samtleben, 1979), corresponds with the lithology of the interval. The lack of bioerosion and encrustation suggests that the residence time in the taphonomic active zone was short. Dysoxia, or turbid waters, could have prevented settlement of bioeroders and encrusters. Bioturbation may have caused a more or less random orientation of the shells. Bioturbation has frequently been assumed to be a major source of breakage; however, there are no case studies supporting this assumption (Zuschin et al., 2003). Predatory organisms could have fragmented some shells; however, neither borings nor scratch marks have been found on the shells.

Lewy \& Samtleben (1979) noted that valves of Corbula gibba have a tendency to split apart into two along conchiolin layers. Decomposition of the layers weakens the shell mechanically in the early stages of fossilization. Although commonly seen in corbulid bivalves, the phenomenon was not observed in the present study.

The extensive dissolution is likely to be related to cold bottom water undersaturated with respect to calcium carbonate (Lewy, 1975). Undersaturated bottom water may occur in areas of the western Baltic Sea and affects shells of mollusks living close to the bottom, e.g., Corbula gibba. In particular, when the periostraca have deteriorated biologically or mechanically, the effect of dissolution increased (Lewy, 1975; Lewy \& Samtleben, 1979). The effect of interstitial acidity due to bacterial decay of organic matter may be the cause for dissolution (Aller, 1982). However, distinction between preburial and post-burial dissolution (e.g., by groundwater) appears to be impossible in the present case.

Interval D (105- $0 \mathrm{~cm})$

\section{Description}

Generally well-preserved shells exceeding one centimetre in length are dispersed and randomly oriented within the structureless sediment. The shells are fragmented and dissolved to a moderate degree. Remains of periostracum are commonly preserved. There are no evidence of bioerosion and encrustation. A number of shells are articulated and preserved with remains 
of periostracum, in particular those of Paphia senescens and Arctica islandica. These two species are better preserved in this interval than in the others.

\section{Interpretation}

Shells that show a high degree of preservation are probably preserved within-habitat. Transportation within the habitat is likely to have caused damage to their periostracum along with disarticulation and fragmentation of the shells. The random shell orientation and lack of layering provides the only evidence for bioturbational mixing of the shells in this structureless mud. The interval probably represents deeper offshore deposition. The shells of Paphia senescens are the least fractured and dissolved in this interval compared to the other intervals. The lower degree of shell dissolution may be related to the fine-grained texture of the sediment.

\section{Discussion}

\section{Shell structures of Paphia senescens}

Paphia senescens is widely distributed and abundant in Eemian marine deposits in Denmark and the southern North Sea, being important as biostratigraphic index fossil (Nordmann, 1913, 1928, 1931; Sorgenfrei, 1946). During the past century, however, the taxonomy of this species has been discussed in relation to $P$. aurea and other resembling taxa (e.g., CerulliIrelli, 1908; Nordmann, 1913, 1931; Brouwer, 1941; Pelosio \& Raffi, 1974; Panetta \& Dell'Angelo, 1977). There are no obvious shell structural differences between $P$. aurea and $P$. senescens that support an obvious taxonomic separation between them. However, Cerulli-Irelli (1908) considered the morphology of 'Tapes senescens' as very distinctive and indeed characteristic from other variants. Instead, Nordmann $(1913,1931)$ was much in doubt about the relationship between 'Tapes senescens' and 'Tapes aureus'. Juvenile specimens of the two species are very similar. 'Tapes senescens' was only characterized by larger shell size and thickness, prominent beaks and the characteristic sculpture on the posterior end. None of these features seems sufficiently stable for taxonomy (Nordmann, 1931).

Before these species can be assigned to the same taxon, their shell structures must be compared with those of various Paphia species and combined with morphometric analyses. The analysis performed by Brouwer (1941) on shells of $P$. aurea and P. senescens, indicates that they overlap at least partially in shell size and proportion, sculpture and geographic range. Similar studies need to be conducted on Eemian specimens from the present areas of the Baltic Sea across southern Jutland to the North Sea. This may demonstrate a potential morphometric gradient caused by shifts in salinity and substrate properties. Because Italian Pliocene shells of Venerupis (Tapes) commonly became thin within lagoonal environments, and when living in open-marine infralittoral and circalittoral environments they were larger and more sculptured (Caretto, 1985), their potential usefulness in paleoceanography is high. Venerupis rhomboides and other species were studied by Eager (1978) to understand shell shape and possible environmental modification of growth pattern. Many factors may influence shell shape, including for example trophic and hydrodynamic conditions and presence of predators.

\section{Paleoenvironments and preservation state}

To clarify the usefulness of the taphonomic analysis, the sealevel development during the Eemian can be compared with previous faunal studies. Nordmann (1908) stated that the mollusk faunas indicate that the Eemian deposits within Ristinge Klint was deposited under rising saline conditions and increasing water depth. The lower coarse-grained part is characterized by mollusks indicating brackish-water conditions, whereas the upper more fine-grained part was formed in a fjord-like marine environment. The uppermost part shows somewhat deeper and relatively open marine conditions (Nordmann, 1908; see also Andersson, 1898). The early stratigraphic succession of Eemian sediments reflects a rise in groundwater level leading to deposition of the 'Shiny clay' in lakes. Later, the area became inundated by a shallow-marine sea, where the 'Cyprina clay' was formed, apparently during a gradual rise in sea level (Nordmann, 1908; Kristensen et al., 2000). The successive foraminiferal and ostracod assemblages indicate a very similar environmental development (Kristensen et al., 2000). In addition, species diversity and the relative abundance of dinoflagellates show an upsection increase in marine influence; however, fully marine conditions were not reached (Head \& Gibbard, 2000).

The environmental development is consistent with the succession of the four states of preservation.

1. The lowermost interval A $(232-187 \mathrm{~cm})$ contains lenses of shell debris of Mytilus edulis and indeterminate species from shoreface or foreshore environments. The debris was probably transported in offshore direction. Deposition within the transition from shoreface to offshore is indicated by the lenses as well as the sandy nature of the sediment (see Aigner \& Reineck, 1982; Aigner, 1985). This implies a zone of non-deposition between 'Freshwater sand' and brackish shoreface sediments.

2. The interval $B(187-120 \mathrm{~cm})$ contains four shell-rich horizons deposited, or at least extensively reworked, during storm events. The shell-rich horizons are composed of a low diverse fauna dominated by endobenthic Paphia senescens and epibenthic Mytilus edulis. Mytilus edulis typically lives attached by its byssus to large particles within the intertidal zone and shoreface. The shells probably were transported into an upper offshore environment. The four shell-rich horizons yield similar preservation patterns (Tables 3, 4). As tidal features are absent, the shell-rich horizons cannot 
be interpreted as tidal flat tempestites (see Reineck \& Gerdes, 1996), and thus, landward transport of the shells appears unlikely. This is also supported by the change in fauna observed as sea level rose. In addition, the shell-rich horizons do not display consistent changes in fossil composition that would be expected if they reflected changes in water depth.

3. Interval C (120 - $105 \mathrm{~cm})$ contains numerous small shells of Corbula gibba. Each of the shells contains only a few growth increments that may have formed annually (unpublished data). The growth rate of Corbula gibba is rapid during the first few months of its juvenile stage; the shells reach a size similar to the present shells (Jensen, 1990). Corbula gibba is able to survive long periods of oxygen deficiency (e.g., Christensen, 1970; Rosenberg, 1980; Jensen, 1990). Thus, the high number of articulated specimens of Corbula gibba and the low diversity of macrobenthos, may be explained by low concentration of oxygen at the sea bottom. 0r, being an opportunist, it may simply be the first to colonize a new environment. It can be very difficult to distinguish between these two modes, but taphonomic evidence is critical. Large numbers of adult-sized specimens, especially disarticulated specimens associated with storm beds, tend to argue for opportunistic colonization rather than oxygen deficiency (e.g., Rodland \& Bottjer, 2001). As the specimens of Corbula gibba within 'Cyprina clay' are juvenile and articulated, however, they probably indicate low concentration of oxygen. Corbula gibba has been considered as characteristic for the short-lived zone along a gradient of organic enrichment (Pearson \& Rosenberg, 1978). The interval rich in Corbula gibba suggests that this area of the Eemian Baltic Sea became enriched with organic matter.

4. The D interval $(105-0 \mathrm{~cm})$ is characterized by well-preserved large shells of Paphia senescens and Arctica islandica. This reflects calm conditions with gradual sedimentation of mud below storm wave base. Although the tolerance of Arctica islandica to survive periods of hypoxia and hydrogen sulphide is well known (e.g., Theede, 1973; 0eschger \& Storey, 1993), the co-occurrence of Acanthocardia echinata and Paphia senescens indicate that this part of the Eemian Baltic Sea was less depleted in oxygen than the more westerly area. According to Funder \& Balic-Zunic (2004), the occurrence of Eemian Arctica islandica and Corbula gibba at the sea cliff Mommark on Als island, which is located $40 \mathrm{~km}$ west of Ristinge Klint, is indicative of hypoxia. At this site, however, these species are associated with juvenile specimens of Ostrea edulis and Paphia aurea. Alternatively, substrate consistency similar to soupground could have caused juvenile bivalve mortality. Muddy sediment may under turbulent conditions have clogged up gills of these filter feeders.
Characterization of bottom-water conditions is important for the understanding of the Eemian fauna development and distribution within the basins of the Baltic Sea region (cf. Knudsen, 2004). Funder \& Balic-Zunic (2004) reported oxygen deficiency from the Mommark site of the Eemian Baltic Sea, reflecting local conditions within a threshold basin. They documented a low-diversity molluscan fauna and a relatively high amount of pyrite; however, the latter cannot be used alone as an anoxia indicator of bottom-water conditions (e.g., Berner \& Raiswell, 1983; Raiswell \& Berner, 1985). Even high amounts of pyrite can be obtained from bioturbated sediments, where irrigation of burrows may work as a biological pump of diagenetic reactive components into the sediments (Berner, 1980; Berner \& Westrich, 1985). Pyrite formation is well known from modern environments to be influenced by microbial sulphate reduction, and availability of seawater sulphate, reactive iron and organic matter. These are necessary to convert sulphate and iron to pyrite, either directly or via precursors as metastable iron mono- and polysulphides (Berner, 1984; Drobner et al., 1991; Wilkin \& Barnes, 1996).

Details of the faunal distribution and taphonomy are consistent with an origin by muddy background sedimentation as well as storm events reworking shells from shallower parts of a fjord-like environment. The sedimentary succession may have formed during a smoothly deepening upwards. The shells from Ristinge Klint have particularly been affected by three taphonomic processes, i.e., disarticulation, dissolution and fragmentation. Macroscopic and microscopic borings occur in a small part of the shells only. Some abrasion is evident in the $\mathrm{B}$ interval. The lack of encrustations and only a few borings suggest that the shells were only shortly exposed on the sea bottom, which is confirmed by the graded sediment overlying the shell-rich horizons. However, encrustation can occur within a matter of weeks or months, if the fauna is present. This indicates either a lack of encrusters, supporting the hypoxia argument, or rapid burial. The occurrence of Nassarius reticulatus and Paphia senescens between the shell-rich horizons indicates that the sea water contained enough oxygen for them to colonize the sea bottom with larvae during periods of normal weather conditions. Only disarticulated plates of Balanus improvisus are present in the intervals B and D. Samples taken in the intervals $A$ and $B$ have a higher proportion of shells with poor articulation and high levels of dissolution and fragmentation. In contrast, those from the intervals $C$ and $D$ have a higher proportion of paired shells and a lower level of dissolution. The difference in dissolution is probably related to the larger content of sand and shells in the intervals A and B, which can lead to higher connectivity and porewater flow. Cold bottom water in brackish settings can be undersaturated with respect to calcium carbonate, and thus, the shells can be etched and leached (Alexandersson, 1972). This may explain the enhanced shell dissolution. 
The western part of the Eemian Baltic Sea was characterized by fjords and islands (Fig. 9). The Danish Belt area appear to have been closed until ca. 650 years into the Eemian, shown by a marked increase in salinity (Kristensen et al., 2000). Nearly fully marine conditions were reached ca. 2500 years into the Eemian. The stratigraphic change in shell dissolution discussed above may be related to the opening of the Danish Belts. At present, the Baltic Sea also is low saline and is characterized by reduced oxygenation in deeper parts of the basin (Fonselius, 1969; Rosenberg, 1980). The extent of hypoxia increases with retardation of water renewals (Fonselius, 1969), and infrequent renewal may explain the periods of oxygen deficiency inferred for this sedimentary succession.

\section{Timing of tempestites}

The presence of the tempestites indicates discontinuity surfaces, which may have regional implications for biostratigraphic studies. Possible reworking of microfossils may have occurred

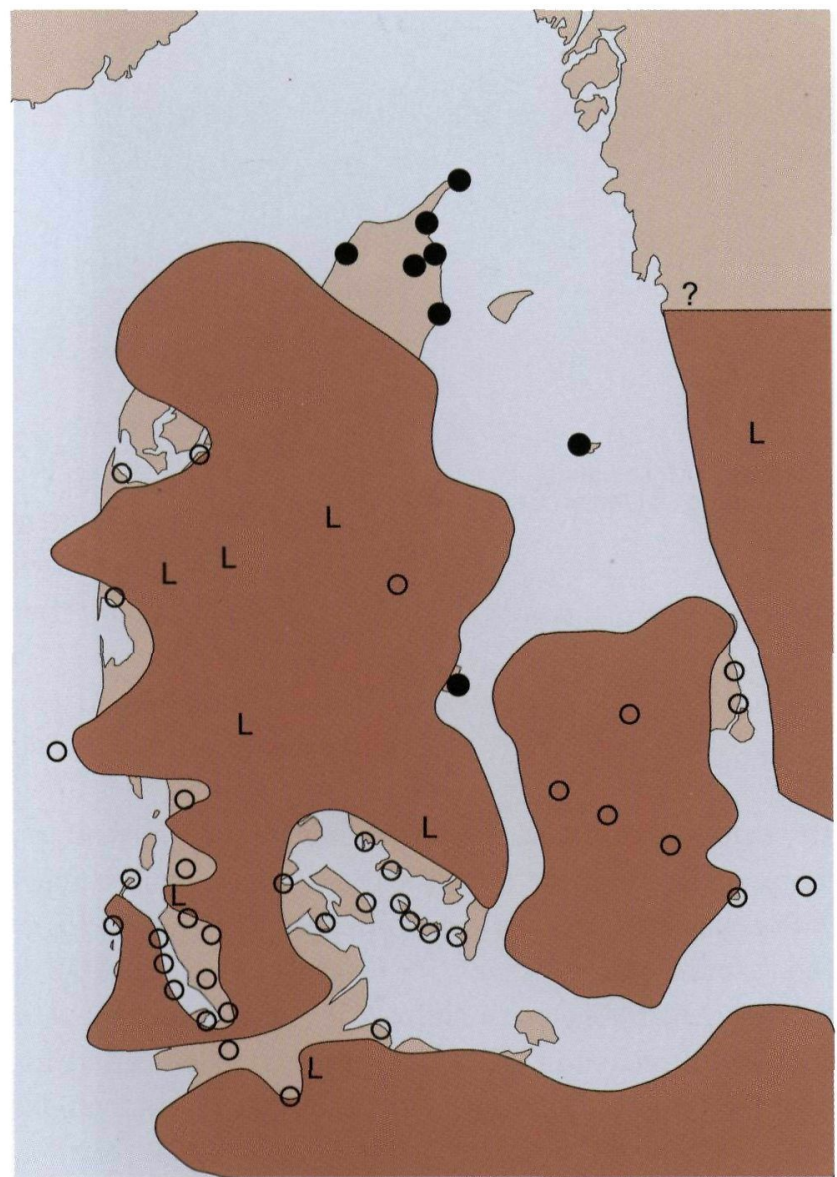

Deeper marine

O Shallow marine

L Lacustrine episodically during the deposition of the 'Cyprina clay'. The biostratigraphic investigation by Kristensen et al. (2000), however, did not reveal any major hiatus in the Eemian succession. Nevertheless, the timing of the tempestites is crucial to know to further knowledge on the frequency of the storm events. Kristensen et al. (2000) recorded a pollen succession within Ristinge Klint that can be correlated with the Bispingen succession of annually lamination (Müller, 1974) for time estimation (Fig. 10). The succession at Ristinge Klint correlates with Jessen \& Milthers' (1928) pollen zones E2-E5, corresponding to about 3400 years (Kristensen et al., 2000). Assuming constant sedimentation rates, the average time between the deposition of the three uppermost tempestites is estimated to be approximately 160 years.

The continuous shell horizons may be traceable to Trappeskov Klint and Vejnæs Nakke on the southern coast of the island $Æ r ø$, located west off Ristinge Klint. Shell horizons can be recognized at these sea cliffs (Nordmann, 1908) as well as on the western tip of $€$ $\boxminus$. The Eemian marine succession of $Æ r \varnothing$ is slightly richer in species, indicating the presence of

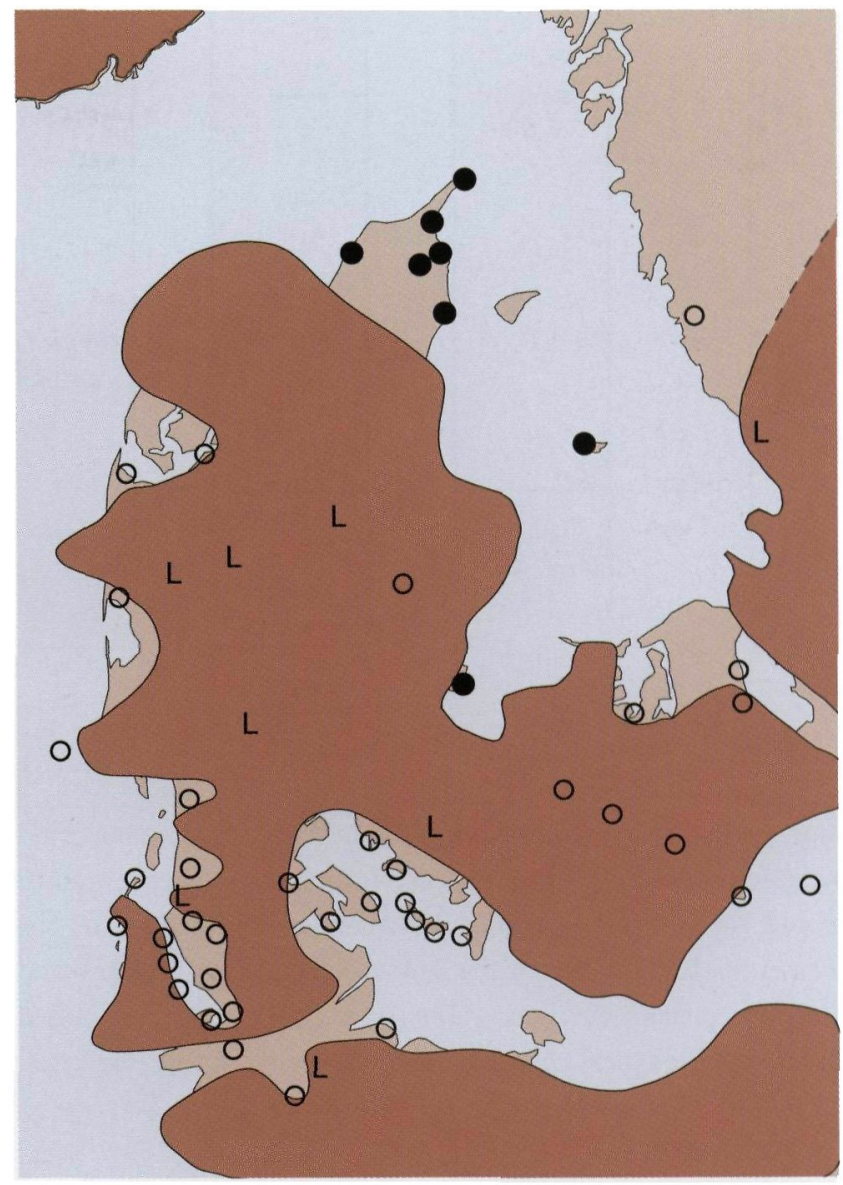

b.

Fig. 9. Schematic reconstructions of the Eemian coastline; a. Maximum extent of the Eemian sea (after Knudsen, 1994; Seidenkrantz et al., 2000); b. Before opening of the Danish Belts. Dark and light brown shades show Eemian and Recent terrestrial areas, respectively. Known locations of Eemian deposits are indicated with symbols. 


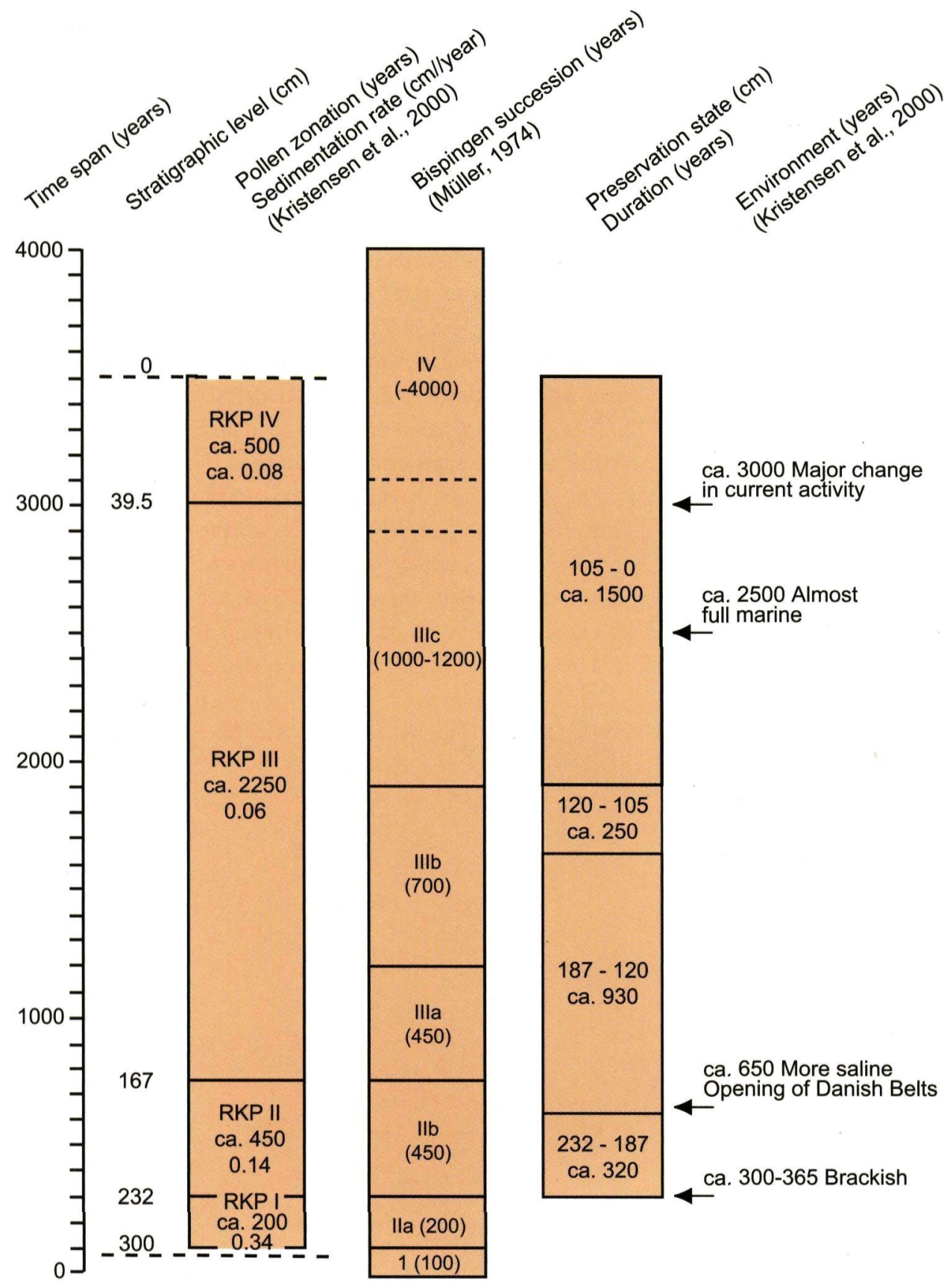

Fig. 10. Timing of the states of preservation and storm tempestites. Correlation with the Bispingen succession of annually lamination is based on the biostratigraphy by Kristensen et al. (2000). more saline waters (Nordmann, 1908). The shell horizons could have formed during the same two storm events. Their presence would then have regional hydrodynamic implications for the western Baltic Sea during the Eemian Interglaciation. However, the biostratigraphy of the Ærø sites has yet to be studied before chronological correlations to Ristinge Klint can be done.

\section{Conclusions}

Four lithological intervals characterized by distinct states of mollusk preservation have been recognized in the cliff Ristinge Klint (Eemian). The stratigraphic succession of preservation states is consistent with a deepening of the area, i.e., a change from shallow brackish to deeper marine conditions. The shells are worst preserved in the lowest interval and increasingly better preserved in the overlying three intervals, concomitant with a general decrease in the hydrodynamic energy levels in the depositional setting. The second lower interval is characterized by shell-rich horizons interpreted as short-term tempestites related to storm-like episodes. Pollen correlation with the Bispingen succession indicates that three storm-like episodes occurred at a frequency of about 160 years. As indicated by faunal composition and preservation, oxygen deficiency characterized the succeeding interval, suggesting a short-lived period of organic enrichment in the area. Interspecific differences in shell preservation are recognized in the shell-rich horizons and are at least partly related to inherent shell properties. 


\section{Acknowledgements}

This paper has benefited from a postdoctoral scholarship (No. 04-0256/20) to Jan KN kindly provided by the Carlsberg Foundation. Data originate from a doctoral study funded by the Faculty of Science, University of Copenhagen. We also acknowledge the postdoctoral scholarships to SH and DR from the Koneen Säätiö Foundation and the Humboldt Foundation, respectively. Thanks are due to Phil Gibbard (Cambridge) and Peter Kristensen (Aarhus) for introducing Jan KN to Ristinge Klint. Nils-Martin Hanken (Tromsø) and Sten Lennart Jakobsen (Copenhagen) kindly gave us insight into the paraffin oil method and its usefulness to disaggregate clay-rich samples. Also thanks to Kristian Bangert and Lotte Qvist Nielsen (Copenhagen) for field assistance. Martin Zuschin (Vienna) kindly gave comments on an early draft of the manuscript. Henning Scholz (Berlin) and Frank Wesselingh (Leiden) are thanked for their constructive reviews.

\section{References}

Aigner, T., 1985. Storm Depositional Systems, Dynamic Stratigraphy in Modern and Ancient Shallow-Marine Sequences. Springer-Verlag (Berlin): 174 pp.

Aigner, T. \& Reineck, H.-E., 1982. Proximality trends in modern storm sands from the Helgoland Bight (North Sea) and their implications for basin analysis. Senckenbergiana Maritima 14: 183-215.

Alemany, J.A., 1986. Estudio comparado de la microestructura de la concha y el enrollamiento espiral en V. decussata (L. 1758) y V. rhomboides (Pennant, 1777) (Bivalvia: Veneridae). Bollettino Malacologico 22: 139-152.

Alemany, J.A., 1987. Microestructura de la concha de Venerupis aurea (Gmelin, 1791). Revisión microestructural de la subfamilia Tapetinae (Bivalvia: Veneridae). Boletin de la Real Sociedad Española de Historia Natural, Seccion Geologica 83: 15-24

Alexandersson, E.T., 1972. Micritization of carbonate particles: processes of precipitation and dissolution in modern shallow-marine sediments. Bulletin of the Geological Institution of the University of Upsala, New Series 3: 201-236.

Allen, J.R.L., 1984. Experiments on the settling, overturning and entrainment of bivalve shells and related models. Sedimentology 31: 227-250.

Aller, R.C., 1982. Carbonate dissolution in nearshore terrigenous muds: The role of physical and biological reworking. Journal of Geology 90: 79-95.

Allman, M. \& Lawrence, D.F., 1972. Geological Laboratory Techniques. Blandford Press (London): $355 \mathrm{pp}$.

Andersson, F., 1898. Über die quartäre Lagerserie des Ristinge Klint auf Langeland. Eine biologisch-stratigraphische Studie. Bulletin of the Geological Institution of the University of Upsala 3 (1896-1897): 115-180.

Berner, R.A., 1980. Early Diagenesis: A Theoretical Approach. Princeton University Press (Princeton): $241 \mathrm{pp}$.

Berner, R.A., 1984. Sedimentary pyrite formation: An update. Geochimica et Cosmochimica Acta, 48: 605-615.

Berner, R.A. \& Raiswell, R., 1983. Burial of organic carbon and pyrite sulfur in sediments over Phanerozoic time: A new theory. Geochimica et Cosmochimica Acta 47: 855-862.
Berner, R.A. \& Westrich, J.T., 1985. Bioturbation and the early diagenesis of carbon and sulfur. American Journal of Science 285: 193-206.

Brouwer, J., 1941. Over de werkelijke verschillen tusschen Paphia senescens Cocc. en Paphia aurea (Gmel). Basteria 6: 37-48.

Bøggild, O.B., 1930. The shell structure of the mollusks. Det Kongelige Danske Videnskabernes Selskabs Skrifter, Naturvidenskab og Mathematik Afdeling, 9. Series, 2: 233-326.

Cadêe, G.C., 1994. Eider, shelduck, and other predators, the main producers of shell fragments in the Wadden Sea: palaeoecological implications. Palaeontology 37: 181-202.

Caretto, P.G., 1985. Notizie sulla presenza dei Lamellibranchi Venerupis aurea (Gmelin, 1790) e V. geographica (Chemnitz, 1784) nel Pliocene piemontese. Atti della Società italiana di Scienze naturali e del Museo civico di Storia naturale di Milano 126: 283-301.

Caretto, P.G., 1986. Il Lamellibranco Venerupis pullastra (Montagu, 1803) nel Pliocene del Piemonte (Italia, NW). Atti della Società italiana di Scienze naturali e del Museo civico di Storia naturale di Milano 127: 128-140.

Carter, J.G., 1990. Evolutionary significance of shell microstructure in the Palaeotaxodonta, Pteriomorphia and Isofilibranchia (Bivalvia: Mollusca). In: Carter, J.G. (ed.): Skeletal Biomineralization: Patterns, Processes and Evolutionary Trends. Van Nostrand Reinhold (New York): vol. 1: 136-297.

Carter, J.G., Lutz, R.A. \& Tevesz, M.J.S., 1990. Shell microstructural data for the Bivalvia. Part VI. Orders Modiomorphoida and Mytiloida. In: Carter, J.G. (ed.): Skeletal Biomineralization: Patterns, Processes and Evolutionary Trends. Van Nostrand Reinhold (New York): vol. 1: 391-411.

Cerulli-Irelli, S., 1908. Fauna malacologica mariana. Leptonidae, Galeommidae, Cardiidae, Chamidae, Cyprinidae, Veneridae. Palaeontographia Italica 14: 1-64.

Christensen, A.M., 1970. Feeding Biology of the sea star Astropecten irregularis. Ophelia 8: 1-134.

Cocconi, G., 1873. Enumerazione sistematica dei Molluschi miocenici e pliocenici delle provincie di Parma e di Piacenza. Memorie della Accademia delle Scienze d'Istituto di Bologna, serie III, 3: 1-372.

Drobner, E., Huber, H., Wächtershäuser, G., Rose, D. \& Stetter, K.O., 1990. Pyrite formation linked with hydrogen evolution under anaerobic conditions. Nature 346: 742-744.

Eager, R.M.C., 1978. Shape and function of the shell: A comparison of some living and fossil bivalve molluscs. Biological Reviews 53: 169-210.

Ehlers, J., 1978. Fine gravel analysis after the Dutch method as tested out on Ristinge Klint, Denmark. Bulletin of the Geological Society of Denmark 27: 157-164.

Emery, K.O., 1968. Positions of empty pelecypod valves on the continental shelf. Journal of Sedimentary Petrology 38: 1264-1269.

Fonselius, S.H., 1969. Hydrography of the Baltic deep basins III. Fishery Board of Sweden, Series Hydrography 23: 1-97.

Forchhammer, J.G., 1842. Oversigt over de i Aaret 1841 vundne Resultater af geognostiske Undersögelser. Oversigt over Det Kongelige danske Videnskabernes Selskabs Forhandlinger og dets Medlemmers Arbeider i Aaret 1842, Mödet den 13 ${ }^{\text {de }}$ Mai, 5: 63-65.

Frenzel, P., 1993. Die Ostracoden und Foraminiferen des Pleistozänen Cyprinatons der Insel Rügen, NE-Deutschland/0stsee. Meyniana 45: 65-85.

Funder, S. \& Balic-Zunic, T., 2004. Østersøen led også of iltsvind i Eem. Geologisk Tidsskrift 2004 (2): 26-27. 
Funder, S., Demidov, I. \& Yelovicheva, Y., 2002. Hydrography and mollusc faunas of the Baltic and the White Sea-North Sea seaway in the Eemian. Palaeogeography, Palaeoclimatology, Palaeoecology 184: 275-304.

Futterer, E., 1978a. Hydrodynamic behaviour of biogenic particles. Neues Jahrbuch für Geologie und Paläontologie, Abhandlungen 157: 37-42.

Futterer, E., 1978b. Untersuchungen über die Sink- und Transportgeschwindigkeit biogener Hartteile. Neues Jahrbuch für Geologie und Paläontologie, Abhandlungen 155: 318-359.

Gmelin, J.F., 1791. Caroli Linnaei Systema Naturae per Regna Tria Naturae, Secundum Classes, Ordines, Genera, Species, cum Characteribus, Differentiis, Synonymis, Locis. Editio decima tertia, aucta, reformata. G.E. Beer (Lipsiae): 1 (6): 3021-3910.

Hallman, D.P., Flessa, K.W., Kowalewski, M., Hertweck, G., Aggen, J. \& Carlton, J., 1996. Ternary taphograms and the comparative taphonomy of recent mollusks from the North Sea and the Gulf of California. Senckenbergiana Maritima 27: 67-75.

Head, M.J. \& Gibbard, P.L., 2000. Marine dinoflagellates and palaeoenvironments of the Last Interglacial (Late Pleistocene, Eemian) at Ristinge Klint, southern Denmark. Geoscience 2000. Manchester, U.K., p. 85. http://ggpc-jre1/ celticwww/ Addabstracts.htm

Head, M.J., Gibbard, P.L. \& Grøsfjeld, K., 2001. Dinoflagellates and hydrography of the last interglacial (Eemian, Mikulino) in the Baltic Sea-White Sea region. Baltic Sea Science Congress 2001. Stockholm, p. 79.

Houmark-Nielsen, M., 1987. Pleistocene stratigraphy and glacial history of the central part of Denmark. Bulletin of the Geological Society of Denmark 36: 1-189.

Houmark-Nielsen, M., 1999. A lithostratigraphy of Weichselian glacial and interstadial deposits in Denmark. Bulletin of the Geological Society of Denmark 46: 101-114.

Jensen, J., 1990. Increased abundance and growth of the suspension-feeding bivalve Corbula gibba in a shallow part of the eutrophic Limfjord, Denmark. Netherlands Journal of Sea Research 27: 101-108.

Jessen, K. \& Milthers, V., 1928. Interglacial freshwater deposits in Jutland and northwest Germany. Danmarks Geologiske Undersøgelse, II. Række, 48: 1-380.

Johnson, R.G., 1957. Experiments on the burial of shells. Journal of Geology 65: 527-535.

Johnstrup, F., 1882. Nogle Iagttagelser over Glacialphænomenerne og CyprinaLeret i Danmark. Indbydelsesskrift til Kjøbenhavns Universitets fest i anledning af Hans Majestæt Kongens fødselsdag d. $8^{\text {de }}$ April 1882. J.H. Schultz (Kjøbenhavn): 90 pp.

Kidwell, S.M. \& Bosence, D.W.J., 1991. Taphonomy and time-averaging of marine shelly faunas. In: Allison, P.A. \& Briggs, D.E.G. (eds): Taphonomy: Releasing the Data Locked in the Fossil Record. Plenum Press (New York): 115-209.

Kidwell, S.M. \& Holland, S.M., 1991. Field description of coarse bioclastic fabrics. Palaios 6: 426-434.

Kjær, K.H., Houmark-Nielsen, M. \& Richardt, N., 2003. Ice-flow patterns and dispersal of erratics at the southwestern margin of the last Scandinavian Ice Sheet: signature of palaeo-ice streams. Boreas 32: 130-148.

Knudsen, K.L., 1994. The marine Quaternary in Denmark: a review of new evidence from glacial-interglacial studies. Bulletin of the Geological Society of Denmark 41: 203-218.

Knudsen, K.L., 2004. Marint interglacial i Danmark - nyt og gammelt. Geologisk Tidsskrift 2004, no. 2: p. 25.
Konradi, P.B., 1976. Foraminifera in Eemian deposits at Stensigmose, southern Jutland. Danmarks Geologiske Undersøgelse, II. Række, 105: 1-54.

Kowalewski, M., Flessa, K.W. \& Hallman, D.P., 1995. Ternary taphograms: triangular diagrams applied to taphonomic analysis. Palaios 10: 478-483.

Kristensen, P., Gibbard, P., Knudsen, K.L. \& Ehlers, J., 2000. Last interglacial stratigraphy at Ristinge Klint, South Denmark. Boreas 29: 103-116.

Lewy, Z., 1975. Early diagenesis of calcareous skeletons in the Baltic Sea, Western Germany. Meyniana 27: 29-33.

Lewy, Z. \& Samtleben, C., 1979. Functional morphology and palaeoecological significance of the conchiolin layers in corbulid pelecypods. Lethaia 12: 341-351.

Madsen, V., 1916. Ristinge Klint. Nogle nye Iagttagelser. Danmarks Geologiske Undersøgelse, IV. Række, 1, no. 2: 1-32.

Madsen, V., Nordmann, V. \& Hartz, N., 1908. Eem-zonerne. Studier over Cyprinaleret og andre Eem-Aflejringer i Danmark, Nord-Tyskland og Holland. Danmarks Geologiske Undersøgelse, II. Række, 17: 1-302, with an atlas.

Müller, H., 1974. Pollenanalytische Untersuchungen und Jahresschichtenzählungen an der eem-zeitlichen Kieselgur von Bispingen/Luhe. Geologisches Jahrbuch A21: 149-169.

Nielsen, J.K., 2004. Taphonomy in the light of intrinsic shell properties and life habits: marine bivalves from the Eemian of northern Russia. Paläontologische Zeitschrift 78: 53-72.

Nielsen, J.K. \& Funder, S., 2003. Taphonomy of Eemian marine molluscs and acorn barnacles from eastern Arkhangelsk region, northern Russia. Palaeogeography, Palaeoclimatology, Palaeoecology 191: 139-168.

Nordmann, V., 1908. Molluskfaunaen i Cyprinaleret og Mellem-Europas andre Eem-aflejringer. Studier over Interglaciale aflejringer i Danmark, Holland og Nord-Tyskland. Doctoral thesis, University of Copenhagen. C.A. Reitzel (Kjøbenhavn): 157 pp. (form part of Madsen et al., 1908).

Nordmann, V., 1913. Tapes senescens Doederlein og Tapes aureus Gm. var. eemiensis Nordm. Videnskabelige Meddelelser fra Dansk Naturhistorisk Forening 65: 287-300.

Nordmann, V., 1928. La position stratigraphique des Dépôts d'Eem. Danmarks Geologiske Undersøgelse II. Række, 47: 5-81.

Nordmann, V., 1931. Eem-Havet. Naturens Verden 15: 302-324.

Oeschger, R. \& Storey, K.B., 1993. Impact of anoxia and hydrogen sulphide on the metabolism of Arctica islandica L. (Bivalvia). Journal of Experimental Marine Biology and Ecology 170: 213-226.

Panetta, P. \& Dell'Angelo, B., 1977. I Molluschi dei fondi detritici costieri del Golfo di Taranto. In: Cinelli F., Fresi E. and Mazzella L. (eds): Atti IX Congresso S.I.B.M., Lacco Ameno d'Ischia (Napoli) 1977: 303-314.

Pearson, T.H. \& Rosenberg, R., 1978. Macrobenthic succession in relation to organic enrichment and pollution of the marine environment. Oceanography and Marine Biology: an Annual Review 16: 229-311.

Pelosio, G. \& Raffi, S., 1974. Osservazioni su Arctica islandica ed altri Lamellibranchi del Calabriano dell'Emilia occidentale. Acta Naturalia de l'Ateneo Parmense 10: 347-367.

Raiswell, R. \& Berner, R.A., 1985. Pyrite formation in euxinic and semi-euxinic sediments. American Journal of Science 285: 710-724.

Reineck, H.E. \& Gerdes, G., 1996. A seaward prograding siliciclastic sequence from upper tidal flats to salt marsh facies (southern North Sea). Facies 34: 209-218.

Richter, R., 1942. Der Einkippungsregel. Senckenbergiana 25: 181-206. 
Rodland, D.L. \& Bottjer, D.J., 2001. Biotic recovery from the end-Permian mass extinction: Behavior of the inarticulate brachiopod Lingula as a disaster taxon. Palaios 16: 95-101.

Rogalla, N.S. \& Amler, M.R.W., 2003. Abrasion an rezenten Bivalvenschalen. Geologica et Palaeontologica 37: 107-148.

Rosenberg, $\boldsymbol{R} ., 1980$. Effect of oxygen deficiency on benthic macrofauna in fjords. In: Freeland, H.J., Farmer, D.M. \& Levings, C.D. (eds): Fjord 0ceanography. Plenum Press (New York): 499-514.

Rosenkrantz, A., 1945. Nye Bidrag til Forstaaelsen af Ristinge Klints Opbygning. Meddelelser fra Dansk Geologisk Forening 10 (1944): 431-435.

Salazar-Jimenez, A., Frey, R.W. \& Howard, J.D., 1982. Concavity orientations of bivalve shells in estuarine and nearshore shelf sediments, Georgia. Journal of Sedimentary Petrology 52: 565-586.

Seidenkrantz, M.-S. \& Knudsen, K.L., 1997. Eemian climatic and hydrographical instability on a marine shelf in northern Denmark. Quaternary Research 47: 218-234.

Seidenkrantz, M.-S., Knudsen, K.L. \& Kristensen, P., 2000. Marine late Saalian to Eemian environments and climatic variability in the Danish shelf area. Geologie en Mijnbouw, Netherlands Journal of Geosciences 79: 335-343.

Sjørring, S., 1983. Ristinge Klint. In: Ehlers, J. (ed.): Glacial Deposits in NorthWest Europe. A.A. Balkema (Rotterdam): 219-226.

Sjørring, S., Nielsen, P.E., Frederiksen, J., Hegner, J., Hyde, G., Jensen, J.B. Mogensen, A. \& Vortisch, W., 1982. Observationer fra Ristinge Klint, feltog laboratorieundersøgelser. Dansk Geologisk Forening, Årsskrift for 1981: 135-149.

Sorgenfrei, T., 1946. Mindre Meddelelser fra Danmarks Geologiske Undersøgelses Borearkiv. Meddelelser fra Dansk Geologisk Forening 10 (1945): 561-590.

Tebble, N., 1976. British Bivalve Seashells. A handbook for Identification. Her Majesty's Stationary Office (Edinburgh): 2. edition, $212 \mathrm{pp}$.

Theede, H., 1973. Comparative studies on the influence of oxygen deficiency and hydrogen sulphide on marine bottom invertebrates. Netherlands Journal of Sea Research 7: 244-252.

Wilkin, R.T. \& Barnes, H.L., 1996. Pyrite formation by reactions of iron monosulfides with dissolved inorganic and organic sulfur species. Geochimica et Cosmochimica Acta 60 (21): 4167-4179.

Wilson, R.L., 1965. Techniques and materials used in the preparation of vertebrate fossils. Curator 8: 135-143.

Yonge, C.M., 1946. On the habits and adaptations of Aloidis (Corbula) gibba. Journal of the Marine Biological Association of the United Kingdom 26: 358-376.

Zuschin, M., Stachowitsch, M. \& Stanton, R.J. Jr., 2003. Patterns and processes of shell fragmentation in modern and ancient marine environments. EarthScience Reviews 63: 33-82. 